\title{
AN INDIAN PERSPECTIVE ON THE EVOLUTION OF INTERNATIONAL LAW ON THE THRESHOLD OF THE THIRD MILLENNIUM
}

\author{
V.S. Mani*
}

\begin{abstract}
"It is perhaps imagined by some people that international law took shape under Grotius or some other scholars in the West, and that there was no such thing in the countries of Asia or elsewhere. That, of course, cannot be correct, because if there is any kind of civilised order there must be some kind of international law and ideas in regard of the relationships of States."
\end{abstract}

Jawaharlal Nehru

\section{INTRODUCTION}

An attempt is made here to portray an overview of some of the aspects of international law as it evolved, and as it was understood in India through the centuries. The selection of materials for research has necessarily been eclectic. Any endeavour of this kind is beset with difficulties. First, delving into a more than five-thousand-year-old civilisation is itself a daunting task. Second, the record of history of the ancient period has, by and large, been an eclectic reconstruction based on archaeological findings as and when they come to light and on the later literary and religious works. Indeed, this is largely true of the Middle Ages as well, when some travelogues and records of foreign pilgrims, travellers or ambassadors had started appearing. Even these writings of foreigners might have revealed flaws in conceptual or cultural misunderstanding. Third, most European, predominantly English, works on Indian history, particularly of the colonial period, have not exactly been unbiased.

For the convenience of discussion, the historical survey of India's perspectives on international law is divided into four periods, namely (1) the

\footnotetext{
* Professor, International Legal Studies, Jawaharlal Nehru University, New Delhi, India 110067.

1 Address on the occasion of the inauguration of the Indian Society of International Law, New Delhi on 29 August 1959, reprinted in 1 IJIL (1960-61) 5-9, 6.
}

Asian Yearbook of International Law, Volume 9 (B.S. Chimni et al., eds.)

(C) 2004 Koninklijke Brill NV. Printed in The Netherlands, pp. 31-77. 
ancient period (up to $711 \mathrm{AD}$ ), (2) the middle ages (711 to 1600), (3) the colonial period (1600 to 1947), and (4) the modern period (since 1947). ${ }^{2}$

\section{ANCIENT INDIA ${ }^{3}$}

The ancient India generally encompasses the early Vedic period (starting from $3000 \mathrm{BC}$ ) and the early empires (the Mauryas, the Guptas, the Kushans, the Pushyabhutis, the Pratiharas, the Palas, the Seras, the Chalukyas, the Rashtrakutas, the Pallavas, the Cholas, etc.). The Mohanjodaro and the Harappan excavations of the 1920s revealed the existence of a civilisation dependent on river basins. The advent of the Aryans from Central Asia, obviously a slow migration of a people spread over a few centuries, gave way to the establishment of their pastoral tribal settlements, perhaps into selfsufficient villages. The four-fold division of labour in these village communities led to its transformation into the caste system, which over time petrified into a rigid system, synonymous with social stratification symbolised by levels of deprivation of human rights, worst hit being the lowest caste, the Sudras. This degeneration took place perhaps towards the end of the ancient period. ${ }^{4}$

\footnotetext{
2 From a strictly historical point of view, the colonial period is included in the "modern period", but to many countries in Asia and Africa, colonialism was an historical anachronism, and it could not, therefore, be rightly considered part of the "modern" period. The above classification of historical periods is by and large based on R.C. Majumdar, A.C. Raychaudhuri and Kalikinkar Datta, An Advanced History of India (London, Macmillan, 1963) - except for separation of the colonial period from the "modern period".

${ }^{3}$ See generally, Nagendra Singh, India and International Law (New Delhi, 1969), H. Chatterjee, International Law and Inter-State Relations in Ancient India Calcutta, 1958), M.K. Nawaz, "The Law of Nations in Ancient India", VI Indian Yearbook of International Affairs (1957), 172-188. C.J. Chacko, International Law in India: Ancient India", 1 IJIL (1960-61) 194-192, 589-598.

${ }^{4}$ It is needless to say that this degeneration took place mainly because the people who formed the upper castes, once in position of power and influence, made sure that that position is perpetuated. In fact Lord Krishna said to Arjuna in the battlefield in the Mahabharata Epic while enunciating his celebrated Gita (which is itself a Holy Book for the Hindus) as follows in chapter IV, stanza 13: "Charturvarnyam mayaa srshtham gunakarmavibhagashah." It means: "The four-fold classification of society that I have established is based on the functions and avocations undertaken by each class of people." As S. Radhakrishnan points out in his commentaries on The Bhagavadgita (New Delhi, India: Blackie \& Son, 2nd edn., 6th Indian Reprint, 1977) 160, "The emphasis is on guna (aptitude) and karma (function) and not Jati (birth). The varna or the order to which we belong is independent of sex, birth or breeding. A class determined by temperament and vocation is not a caste determined by birth and heredity. Evidently, the Lord never meant the original allocation of work He made when He created the human society to be perpetuated in terms of social and economic stratification or any monopoly over enjoyment of privileges or power merely by virtue of a biological accident, namely birth into a particular functional caste. Hence the clarification elsewhere: "Janmanaa jaayate Sudra, Karmanaa jayate Dwija," i.e., "Every man is born as Sudra, and by his efforts/work/choice of avocation he becomes a Brahmin." What happened subsequently
} 
The ancient Indian polity, as it slowly stabilised with a territorial base, threw up, and perhaps came to recognise, a range of international law concepts, principles and rules, as these evolved through the centuries. They encompassed principally those relating to the concept of statehood, diplomatic relations, treaties, religious tolerance, non-use of force, humanitarian law of armed conflict, neutrality, and the Indian brand of imperialism.

\subsection{The state}

Historically, it is very difficult to date the origin of state system in ancient India. There must have been some sense of a concept of state as an autonomous political institution even before the various nomadic, cattle-grazing tribes moved about the river basins. The tribal chiefs must have exercised some of the elements of sovereignty (Prabhutwata), as we know it today. A group of tribes might have elected or accepted a head chief who later came to be called as the Rajan (the king), as has been the case with many ancient societies. Slowly, however, when the tribes discovered agriculture, they must have decided to abandon the nomadic life and they thus settled down along the river basins. This surely gave a territorial foundation as the physical basis for the then evolving polity for exercise of elements of sovereign authority, both to correspond to its responsibility to protect the lives and property of its member communities and to ensure peace and order to enable them to pursue vocations of their choice. ${ }^{5}$

The state (rashtra) in the Vedic period was probably a collection of villages, ruled by a king (rajan) who was "without a rival, and a destroyer of rivals". ${ }^{6}$ The kingship was usually hereditary, but there were also some

\footnotetext{
in the evolution of the Indian society was the institutionalisation of a serious violation of the Lord's dictates, by those who happened to climb the social ladder before others and occupy positions of power and influence, as they ensured the preservation and perpetuation of hereditary enjoyment of the social and economic benefits of what was originally a 'division of labour' unto their own descendants, by effectively preventing social and functional mobility for the subsequent generations. The later interpretations (Srutis and Smrtis) of the Hindu religious scriptures by the upper castes became self-serving and self-perpetuating, bequeathing to the contemporary Indian society the now deep-rooted socio-economic burden of the caste system. This tendency of social exploitation of the 'lowly born' by the people of higher strata also finds place within each caste as well, a fact which is generally ignored, quite wrongly of course. Thus there are sub-castes within the same caste (even among the so-called Sudras) with gradations of social hierarchy, leading to further stratification, and hence exploitation of large sections of society by smaller ones. Radhakrishnan suggests 200 $\mathrm{BC}$ as the approximate date of the poetic rendering of the Gita. See his above work, at 14.

${ }^{5}$ On eventual emergence of territorial states, see generally, Manumdar et al, op. cit., n. 2, 53-55; Jawaharlal Nehru, Glimpses of World History (New Delhi: Oxford UP, 15th Impression, 1999) 23-26 on "The Village Republics of Ancient India"

${ }^{6}$ Majumdar et al, op. cit., n. 2 at 9.
} 
elective monarchies. ${ }^{7}$ There are references to the election of kings in the fourth Veda, i.e., the Atharva Veda, and in the Mahabharata, one of the two Great Epics. At any rate, even where the kingship was not elective, the scriptures emphasised the need for legitimising sovereignty with the people's approval.

The concepts of state, sovereignty, and even kingships, as they subsequently matured on the Subcontinent, were not as simplistic as they have been in Europe or in the Western literature. Functionally, there could be different tiers of statehood, sovereignty or kinship. The Chakravartin or the universal emperor was at once a monarch over a territorial state and a paramount ruler or an overlord over many other states/kingdoms whose rulers might owe allegiance to him. Indeed some of these rulers might themselves be emperors over other monarchies. These relationships could not be pigeonholed into that of the overlord and the vassals of the feudal era of Europe. The kings in ancient India were sovereigns in their own right. The paramount ruler had both the right of allegiance of his subordinate kings and the responsibility for their protection. If he could not fulfil his responsibility, he could not command or demand allegiance either. A king was free to switch allegiance to another paramount ruler, if he were powerful enough to do so, unless he himself became one. ${ }^{8}$

To Kautilya, the architect of the first strong Indian 'territorial' empire, sovereignty was what sovereignty did. Thus, he conceived it as a composite of factors. "The king, the minister, the country, the fort, the treasury, the army and the friend, and the enemy are the elements of sovereignty". ${ }^{9}$ He evidently recognised sovereignty to be the authority of the state both internally and externally. It was the sum total of the ever-changing factors of power, the organisation of government, wealth and other factors of stability of the country, the external support it could ensure and its ability to keep its enemy weak. Except the enemy, the other seven elements, if "possessed of their

\footnotetext{
7 According to Kautilya, people suffering from anarchy at the dawn of human life on earth elected Vaivasvata Manu ('manus' were supreme kings in Hindu mythology appointed by Brahma, the Creator, in the beginning of life after each cycle of total destruction of all life in the universe through downpour of rains and floods, the Pralaya. Each such cycle of creation, growth and destruction of all life is believed to be coterminous with the life of one manu, and is called a 'manuantara') to be their first king and allotted 1/6 of the grain and 1/10 of the merchandise as "sovereign dues". The safety and security of subjects became his responsibility. Samasastry (trans.), Kautilya's Artha Sastra (5th ed., Mysore, 1956) 22-23. Kautilya was also known as Chanakya.

${ }^{8}$ One of the ways in which a king asserted his paramountcy was through an elaborate religious sacrifice called the Aswamedhayagna, at the conclusion of which a specially sanctified horse under the protection of troops was allowed to wander through territories whose kings had the choice of either accepting the paramountcy of the owner of the horse, or challenging his might by blocking or capturing the horse. The Aswamedha sacrifice is depicted in both the classical Sanskrit epics, the Mahabharata and the Ramayana.

9 Samasastry, op. cit., n. 5 at 287.
} 
excellent characteristics are said to be the limb-like elements of sovereignty". ${ }^{10}$ The king, "being possessed of good character and best-fitted elements of sovereignty" is the conqueror or the Chakravartin, i.e., the supreme king commanding the 'wheel or circle' of power residing at its centre. $^{11}$

The ideal of a welfare state was prescribed for the kings to pursue. The Ramarajyam (Rama's rule) as described in the Epic Ramayana was that of heaven on earth. ${ }^{12}$

Rudiments of democracy can be traced to ancient India. There is historical evidence to show that there existed republics with elective governments on the subcontinent. Even under strong central dictatorships, the local government in towns and villages was largely democratic, self-sufficient and self-contained, excepting the obligation to pay the sovereign dues. Jawaharlal Nehru, for instance, underscores this phenomenon of ancient India. "This local autonomy was greatly prized and hardly any king or supreme ruler interfered with it". 13

\subsection{Diplomatic relations}

The kingdoms in India had established substantial trade relations with China, Arabia, Egypt, Greece, Rome, and East Africa. There are references in ancient texts to the import of horses and slaves from Arabia and silk from China, and the export of Indian muslin and indigo to Egypt. The institution of ambassadors (dutas) was regarded as sacrosanct. In the Ramayana, the Monkey God, Hanumaan was sent by Rama as his duta to Raavana's court. The Epic narrates the various violations of diplomatic conduct by Raavana in mistreating Hanumaan. Similarly, Krishna himself went as the duta of the Pandavas to the court of the Kauravas in the Mahabharata.

It may also be noted that there was a deep understanding of the conduct of foreign relations. Indeed, it reflected a projection of inter-individual relations. Before launching an attack on the fortress of Raavana, Hanumaan considered the employment of four upaayas (means or strategies) of foreign policy - saama (negotiations), daana (gifts), bheda (discrimination; divide

\footnotetext{
${ }^{10}$ Ibid. 289.

${ }_{11}$ Ibid. 290. For Kautilya's famous power-political theory of Circle of States or Kings, see, ibid. 290-292.

${ }^{12}$ Kautilya postulated that "Of the king, the religious vow is his readiness for action; satisfactory discharge of duties in his performance of sacrifice; equal attention to all is the offer of fees and ablution towards conservation.

"In the happiness of his subjects lies his happiness; in their welfare his welfare; whatever pleases himself he shall not consider as good, but whatever pleases his subjects he shall consider as good". Ibid. 38 .

13 Jawaharlal Nehru, The Discovery of India (Calcutta: Signet Press, 5th reprint.1948) 4.
} 
and rule) and danda (use of force). Hanumaan dismissed negotiations because one could not negotiate the return of Sita (as for the return of Sita, Raavana must), one could not negotiate with asuras (the demon race: the unrighteous). He dismissed daana, because Raavana could not be bribed with anything that he did not have (as he had already acquired all conceivable material wealth); bheda could not be applied because Raavana was too powerful and the asuras were united under him. What was left then was danda, which could be applied in retaliation to the grave and inexcusable wrong Raavana had wantonly inflicted on Raama. ${ }^{14}$

It was the normal practice for states to send special missions (ad hoc embassies) to each other's capital cities. To denote a special relationship resident ambassadors were also sent. Megasthenes was the Greek ambassador to the Court of Pataliputra. His journals, cumulatively called the Indica, have helped us immensely in reconstructing the Indian history of his time. Ptolemy came as the Egyptian ambassador. Antiochus, son and successor of Selucus Nikator, the Greek Satrap of Persia, was married to Chandragupta Maurya, and also served as an ambassador at Pataliputra. In about 26 BC the King of Pandya of southern India sent a trade mission to Augustus Caesar, and later seven more missions were sent. In about 100 AD the Roman Emperor Trajan received an Indian embassy. In around 360 AD Sri Lanka sent an embassy to the Court of Samudra Gupta. There is a record of King Harsha's embassy to China of 641 AD. ${ }^{15}$ Chalukyas, too, exchanged ambassadors with Sassaniol rulers of Persia. After his conversion to Buddhism, Emperor Asoka sent embassies with a religious mission to Syria, Egypt, Macedonia, Cyrene, Epirus, Burma, and Siam. He sent his son and daughter to Sri Lanka with the same mission. ${ }^{16}$

Kautilya would demand of the ambassadors a high standard of work. He prescribes identical qualifications for appointment of ministers and ambassadors. They should have practical experience, considerable wisdom, purity of purpose, bravery, and loyalty. ${ }^{17}$

\subsection{Treaties}

Treaties played an important role in keeping the peace of nations in ancient India. According to Kautilya, a treaty (sandhi) of peace, "dependent upon honesty or oath, is immutable both in this and the next world". ${ }^{18}$ Emphasising the need to preserve mutuality of benefits as the basis for

14 R. Bhaskaran, "The Four Upayas of Hindu Diplomacy", III Indian Yearbook of International Affairs (1954) 126-130.

15 See generally, Majumdar et al, op. cit., n. 2.

16 Nehru, op. cit., n. 13 at 102.

17 Samasastri, op. cit., n. 7 at 13, 29.

18 Ibid. 341. 
preservation of peace, Kautilya says, "when the profit accruing to kings under an agreement, whether they be of equal, inferior or superior power, is equal to all, that agreement is termed peace (sandhi); when unequal, it is termed defeat (vikrana). Such is the nature of peace and war". ${ }^{19}$ Evidently, Kautilya highlights here the distinction between equal and unequal treaties and also the conflict potential of the latter.

The binding character of a treaty depended upon the nature of the treaty and the security of its performance. It was certain that a breach of a treaty would lead to conflict and a weaker king could ill afford it in his dealings with a stronger king. "It is for this material world only", says Kautilya, "that a security or a hostage is required for strengthening the agreement". ${ }^{20}$ If simple swearing by God or by fire, for example, were unacceptable as a security for performance of a treaty, there could be an insistence upon the provision of wealth, land or hostages (such as the sons of the weaker king).

\subsection{Religious tolerance}

While Europe had to wait until 1648 to achieve even a modicum of recognition of the mutual respect for different religions (that too confined to just two schools of Christianity), there were more ancient examples in India of religious tolerance. Even at the height of rivalry between different sects of Hinduism, and between Hinduism and Buddhism, Asoka the Great (273232 BC), who became a staunch Buddhist after the Kalinga war, proclaimed in one of his edicts thus: "All sects deserve respect for one reason or another. But thus acting a man exalts his own sect and at the same time does service to the sects of other people". ${ }^{21}$ This high moral principle appears to have held sway in India to this day, despite a number of historical, and even contemporary, aberrations.

\subsection{Law relating to foreign trade and shipping}

Since there was considerable foreign trade - a reference to trade missions abroad has already been made above - there is also some evidence of rules relating to foreign trade and shipping. Kautilya suggested the creation of the posts of 19 superintendents for the Maurya Empire. Of these the Superintendents for Commerce, Ships and Passports were noteworthy. The Superintendent of Commerce must show favour to those who imported foreign merchandise. They and the mariners should be taxed less than otherswere. Foreigners importing merchandise enjoyed immunity from being sued for

\footnotetext{
19 Ibid. 318.

20 Ibid. 341.

21 Quoted in Nehru, op. cit., n. 13 at 102.
} 
debts unless they were associated with local partners. The Superintendent of Commerce must keep himself informed of the value of the foreign merchandise in terms of local merchandise. ${ }^{22}$

The Superintendent of Ships was to examine accounts relating to the navigation of ships on oceans, river mouths and inland waters. A fixed tax was to be levied on villages on the seashore. A tax of one-sixth of their catch was to be levied on fishermen. Ports would levy their own customary tolls on merchandise (customs). A sailing fee (vatravetanam) was to be levied on passengers on board the king's vessels. The king's boats could be hired for fishing. Vessels carrying merchandise spoiled by water were to be taxed less than others or exempted from tax altogether. Ships en route to a port were required to pay a toll. Pirate ships and ships that violated the rules of customs and other rules of the port towns could be destroyed. Foreign merchants who were frequent visitors to the country should be favourably treated. Smugglers, criminals and other suspicious characters (including those concealing weapons and explosives) were to be arrested. ${ }^{23}$

The Superintendent of Passports had the power to issue passes on payment of a fee. A pass was necessary to enter the country as well as to leave it. Foreigners violating the pass rules were to be more severely punished than the locals. ${ }^{24}$

\subsection{Non-use of force}

At a time when use of force was the order of the day as the territorial states had just begun to emerge, the later part of the ancient period threw up a great king whose might not only won him many a war, but also taught him the futility of bloody victories and the value of non-violence. Emperor Asoka (273-232 BC) of the Maurya Dynasty, after winning a hard-fought Kalinga war in which 150,000 were held captive, 100,000 slain, and many times that number died otherwise, was "stricken with remorse and disgusted with war". ${ }^{25} \mathrm{He}$ then renounced war as an instrument of national policy.

\subsection{Humanitarian law}

Given the nature of weapons used in ancient times, and the need to protect a primarily pastoral population, it was not surprising that the ancient kings evolved certain laws and customs of warfare more civilised and humane than

\footnotetext{
Samasastry, op. cit., n. 7 at 104-6.

Ibid. 139-142.

Ibid. 157-158.

25 As Jawaharlal Nehru observes, "Unique among the victorious monarchs and captains in history, he decided to abandon warfare in the full tide of victory." See Nehru, op. cit., n. 13 at 101.
} 
those of the present day. For instance, there were agreements between belligerent parties and heads of self-governing village communities whereby the former undertook not to cause damage to the harvests in any way, but to give compensation for any damage caused to the land even unintentionally. ${ }^{26}$

Indeed, except for Kautilya's prescriptions, most other early publicists recorded a general theoretical agreement on a ban of illegitimate methods of warfare - "a war for righteous cause must be righteously conducted". The use of poisoned arrows, concealed weapons, the killing of refugees or persons who were asleep, or destruction of fine buildings, schools, temples and monasteries were all forbidden. ${ }^{27}$ There are copious references to these humanitarian laws in both the Great Epics, as also in the Vedic literature.

In speaking of the operation of a siege, Kautilya's utilitarian advice was that " $(\mathrm{t})$ he territory that has been conquered should be kept so peacefully that people might sleep without any fear". The conqueror should use force only if he were resisted in his peaceful attempt. ${ }^{28}$ Again while speaking on restoration of peace in a conquered country, Kautilya's view was that the conqueror should make every effort to please the people of the conquered territory. "He should follow the friends and leaders of the people". ${ }^{29}$ All prisoners should be released and the conqueror should "afford help to the miserable, helpless and diseased persons". 30

\subsection{Neutrality}

Taking to task some of the classical Western writers such as Oppenheim and Lawrence, ${ }^{31}$ K.R.R. Sastry argues that " $(\mathrm{t})$ hough in Europe the doctrine of neutrality had not been developed until after the eighteenth century, there is evidence that, at least in Maurya times (i.e., in the fourth century BC) a sui generis conception of neutrality was well known in India." 32

In Kautilya's Circle of States (Mandala), presided over by the Invader or Chakravartin (Vijugishu), the Invader was surrounded by eleven kinds of kings: - the Enemy (the neighbouring king), after him the Invader's ally, then the Enemy's ally, then the Invader's ally, next the Enemy's ally, then the Rearward Enemy, after him the Invader's rear friend, then the Rearward

${ }^{26}$ Ibid. 108.

${ }^{27}$ Id.

28 Ibid. 433.

${ }^{29}$ Ibid. 437.

30 Ibid. 438.

${ }^{31}$ On neutrality, see generally K.R.R. Sastry, "A Note on Udasina - Neutrality in Ancient India", III Indian Yearbook of International Affairs (1954) 131-134. He starts his presentation by noting Oppenheim's view (6th ed., vol. II, at 488) that the nations of antiquity could not have been conversant with "neutrality as a legal institution", and Lawrence's assertion (7th edn. at 58) that these nations did not even have appropriate appellations equivalent to modern neutrality.

32 Ibid. 131. 
Enemy's ally, then the ally of the rearward ally, and not included in his Invader-Enemy relationship were a Madhyama (Mediatory) king and a Udaasina (Neutral) king. ${ }^{33}$

The Madhyama king, who would support neither the Invader nor his Enemy, would play a mediatory role between them, if called upon, thereby seeking more power for himself. On the other hand, the Udaasina king would observe strict neutrality in the power struggle between the Invader and his Enemy. In other words, neutrality was an attitude of a state in relation to the Invader and his Enemy. It corresponded to the competitive power relationship between the Invader and the Enemy; furthermore, neutrality could change with any change in the latter relationship. Indeed, for a king to adopt the udaasina attitude, active hostilities between the Invader and the Enemy were not a condition precedent. The king would have nothing to do with the conflictual relationship between the Invader and his Enemy regardless of whether this relationship deteriorated into active hostilities. Quite possibly the udaasina attitude must have been a forerunner of the concept of 'nonalignment' of the Cold War era.

To Kautilya, during war, udaasina (indifference) was of three types: sthaana (keeping quiet without taking any action), asana (withdrawal from hostilities), and upekshana (an attitude of neglect). These nuances of attitudes had to be decided by the neutral king evidently after a cost-benefit analysis in each situation. ${ }^{34}$

Kautilya recommends neutrality to a king in three circumstances: (i) when in his assessment the destructive strengths of himself and those of his enemy were generally equal; (ii) when it would give him time to augment his resources to grow stronger than his enemy; or (iii) when he found that either peace or war would not, despite his superior strength, benefit him more than it would his enemy. ${ }^{35}$ Evidently, there was an element of transience in Kautilya's concept of neutrality, yet it had its own dynamism and independence.

\subsection{Imperialism - Indian style}

The spirit of maritime adventures in search of the mythical golden land (Suvarnabhoomi) in the Far East took Indians to most parts of South-East Asia. There were many trade missions from the eastern coasts of India to these parts. From the second century AD onwards we find references to kingdoms and kings in South-East Asia and Indo-China, bearing Indian names. These kingdoms seem to have flourished between the second and the fifth centuries AD in the Malay Peninsula, Cambodia, Annam, and in the islands

33 Ibid. 132-133; see also Samasastry, op. cit., n.7 at 290-292.

34 K.R.R. Sastry, op. cit., n. 31 at 133.

35 Id. 
of Sumatra, Java, Bali and Borneo. Saivism (a sect of Hinduism) and Buddhism were prevalent in some of these countries. ${ }^{36}$

The rise of these kingdoms is often described as the expansion of Indian imperialism. Some of the Western writers often argue that if the later Western imperialism were justified as "the White man's burden," the early Asian imperialism was based on the theory of the "Brown man's burden", and that each description is as hypocritical as the other.

In reply to a similar view expressed by Chester Bowles, a former US Ambassador to India, ${ }^{37}$ K.K. Pillay asserts that the ancient Indian imperialism in South East Asia and the Western imperialism since the 17th century in Asia and Africa were fundamentally different in a number of respects. ${ }^{38}$ First, the European imperialists were temporary settlers, birds of passage, in the newly discovered lands. The early Indian colonialists set up their colonies and adopted them as their permanent home, despite the fact that there was no pressure of population back in India. Second, the Indian settlers, unlike the Europeans in their colonies, did not form an exclusive class of alien community in their colonies. They mingled freely with the local people and became assimilated over time. There was no community overlordship by the Indian colonialists over the 'natives.'

Third, the Indian colonialists did not follow any policy of exploitation of colonies dictated by the mother country. Commerce was the basic motivational factor. In fact, some of these so-called colonies rose in such a prominence, power and prosperity at a time when their former 'mother countries' on the subcontinent were in the process of disappearence.

Fourth, the influence of Hinduism and Buddhism in these colonies was more comprehensive and powerful than that of the European religions in Europe's colonies. These religions had an Oriental appeal. Kingdoms founded by these religions rose to great heights - the Sailendra (Sri Vijaya) Empire in Sumatra and Java, the Kingdom of Kambojadesa (Cambodia) and the thirteen dynasties of Champa. Most importantly, the establishment of these kingdoms was not followed by the imperial control of the mother country by the despatch of a Warren Hastings or a Wellesley figure; there were no popular uprisings similar to the "Sipoy Mutiny" (i.e., 'soldiers' mutiny', to the British) of 1857, no developments comparable to the Proclamations of Queen Victoria, and no contradictory British parliamentary enactments. The connection with the mother country was religious and cultural, not of political and economic exploitation. Indeed, India did not have a supreme emperor at that time!

\footnotetext{
36 See Majumdar, op. cit., n.2 at 215. According to these authors, the history of these kingdoms is known partly from the Sanskrit inscriptions found in these countries and party from the accounts preserved by the Chinese.

37 Bowles wrote an article in New York Times Magazine, 5 September 1954.

38 K.K. Pillay, "Early Indian Imperialism in the Far East", III Indian Yearbook of International Affairs (1954) 114-125.
} 
These empires in South East Asia left behind glorious monuments of history and marvels of art, incomparable to what little colonial buildings that the British left in India.

It is small wonder that many Indian historians hold an unapologetic view that "the colonial and cultural expansion of India is one of the most brilliant but forgotten episodes of Indian history, of which any Indian may justly feel proud". 39

\section{MEDIEVAL INDIA}

This period broadly covers the Muslim conquests of India, the establishment of a number of Hindu and Muslim kingdoms, and the re-emergence of a central empire, such as the Mughal Empire's consolidation of the greater part of India, to provide the conceptual continuum of Kautilya's Chadravartin. Yet the medieval India seemed to push Indian civilisation on the edge of a precipice, towards the end of that period. Some of the features of the ancient continuum were the principle of religious tolerance, the concept of a welfare state, the secularisation of the state, and humanitarian laws of armed conflict.

\subsection{Religious tolerance}

The clash of the two great religions, namely Hinduism and Islam, produced at once not only a doctrinal rivalry between the two, but at the same time an attempt to tolerate, if not assimilate aspects of each other - a phenomenon repeated now after the rise of Buddhism and Jainism as a challenge to Hinduism towards the end of the ancient period.

Despite the devastation of the Somnath Temple by Mehmud of Ghazni in $1025 \mathrm{AD}$, the feelings of hostility roused by the Turkish aggression wore off over time and King Arjuna of Gujarat had the broadmindedness to endow a mosque erected by the Muslim shop owners of Ormuz and provide it with funds for the conduct of certain Shi'ite festivals. Any surplus of this endowment was to be made over to Mecca and Medina. ${ }^{40}$

The Turko-Afghan rulers came and established themselves in India, generally aware of the need to live in peace with the vast Hindu majority of the people. "Through long association, the growth of the numbers of concerted Indo-Muslim community and influence of several liberal movements in India, the Hindu and Muslim communities came to imbibe each other's thoughts and customs, and beneath the ruffed surface of storm or stress, there

39 Majumdar et al, op. cit., n.2 at 223.

40 Ibid. 185 
flowed a genial current of mutual harmony and toleration in different spheres of life." 41

Many Muslim rulers had Hindu ministers and advisers. Even Vijayanagara Emperors employed Muslims in their military service. The traditional system of administration of districts and villages continued, regardless of who the ruler was.

Hindu-Muslim assimilation had already become a fact of life before the rise of the Mughals. Many poets of the Bhaki (devotion of God) Cult spoke of the fundamental equality of all religions and the unity of Godhead. They preached that the dignity of man lay in the nature of his actions and not in his birth. They protested against the excessive ritualism and formalities in the practice of religion leading to the domination of the priests, and urged the people towards simple devotion to God as the sole path to salvation. Sant (i.e., Saint) Kabir, generally believed to belong to the 15 th century AD, symbolised both in his life and his teachings a spirit of harmony between Hinduism and Islam. "Hindu and Turk are pots of $\{$ the $\}$ same clay; Allah and Ram are but different names", he said.

Sher Shah Suri, who filled part of the interlude (1540-1555) after the Mughal rule began, paved, through his policies of religious tolerance, the way for Akbar. Akbar's Din-I-Illahi was a dream religion drawing on the best aspects of all religions. Shivaji, the devout Hindu king of the Marathas (1630 AD), had great respect for Muslim saints and granted rent-free lands to meet the expenses of illumination of Muslim shrines. He also showed respect for the Christian priests of Surat when he laid siege to that city.

\subsection{Concept of a welfare state}

During an era of many ruthless rulers who, with their often-misguided noblemen, generally revelled in self-aggrandisement, there were also cases of benevolence. The old Kautilyan theories about the king's duties persisted. The king, according to these, existed not for his own good, but owed to the people a duty which he could discharge only by good government. ${ }^{42}$

Mughal Emperor Jahangir's (1605-1627) famous "Chain of Justice" tied between the Shahburji in the Agra Fort and a stone pillar fixed on the banks of the Yamuna symbolised his general attitude towards his subjects. This chain, bearing sixty bells, could be shaken by any individual wishing to bring his grievances to the notice of the emperor. ${ }^{43}$ During the Mughal period, when no written code or decree of laws existed (except for the twelve edits

\footnotetext{
41 Ibid. 401.

42 Krishnadeva Raya of Vijayanagara Empire (16th century) wrote his Amuktamalyadu. "[A] king should rule collecting around him people skilled in statecraft, ... should levy taxes from his people moderately, ... should protect one and all of his subjects ." Ibid. 379

43 Ibid. 463, 470.
} 
of Jahangir, or the Digest of Muslim Law prepared under Aurangzeb, generally known as the Fatwa-I-Alamgiri), judges followed Koranic injunctions, yet observed customary law and equity. On appeal against a judge's decision, the emperor's decision prevailed; provided it did not contradict the sacred laws. ${ }^{44}$

Yet except under a few benign, despotic rulers, the common people were an exploited lot. Of the high incidence of taxation on the peasants, AMIR Khusro, the distinguished poet of that time, had this to say: "every pearl in this royal crown is but the crystallised drop of blood fallen from the tearful eyes of the poor farmer". ${ }^{45}$

\subsection{Secularisation of the state}

Even while religious law (canon law) governed the affairs of administration, and public and private law relations, attempts were made to 'secularise' the state from the influence of religious authorities. The process of secularisation took place in two ways. One was Emperor Akbar's style, which had a close bearing on his concept of a Universal Religion. He commanded the undivided allegiance of his subjects. He did not brook the growing influence of Ulemas (Muslim priests) who exerted "a parallel claim to the obedience of the people". He proceeded step by step to establish himself as the supreme head of the Church (Imam-I-Adil). In September 1579, Akbar promulgated an Infallibility Decree, which made him the supreme arbiter in matters of religions. This was in conformity with his Din-I-Illahi, which gave equal respect to all religions. ${ }^{46}$

The other was the application of canon law (Islamic law) directly by the ruler. Ala-ud-din Khalji (1296-1313) had the courage to challenge for the first time the pre-eminence of the orthodox Church in matters of state. He declared that he could act without the guidance of the Ulemas (Muslim priests) for the political interests of his government. Yet acting on his own he applied what he thought to be the Koranic law. ${ }^{47}$ Aurangzeb, the last powerful Mughal Emperor, adopted a similar practice.

\subsection{Humanitarian laws of armed conflict}

While the ancient traditions of Hinduism and the Islam forbade excesses being committed during war, limits were, in actual practice, seldom placed

\footnotetext{
${ }^{44}$ Emperor Akbar considered himself subject to law. "If I were guilty of an unjust act", he said,

"I would rise in judgement against myself". Ibid. 559

45 Ibid. 39.

46 Ibid. 459-60.

47 Ibid. 306.
} 
on the methods and weapons of warfare. Religious versions of a 'just war' doctrine were fanatically interpreted to permit even the total elimination of the non-believer Invaders such as Mahmud of Ghazni, Mohammad of Ghur, NadirShah of Persia and Timur of Samarquand invaded India mainly to plunder its riches, and therefore their military campaigns were marked by senseless pillage, looting, destruction, and killings. Ala-ud-din Khalji's campaigns into South India were associated with "the sack of cities, the slaughter of the people and the plunder of temples". 48

The institution of political asylum was well known, but then, as it is now, there was no obligation to grant political asylum. For instance, when Chengiz Khan attacked Jalal-ud-din Mangabarni, the last Shah of Kwarazm or Khiva (in the twelfth century), who ran away to Delhi seeking asylum, Itlumish, the then Delhi Sultan of the Slave Dynasty refused to grant it, ${ }^{49}$ perhaps for fear of the great Khan. On the other hand, history records a Bahmini King on the west coast of India granting asylum to Yusuf Adil Khan in the fifteenth century. Yusuf, a son of Sultan Murad of Turkey, later, in 1440, established the Adilshahi Sultanate in Bijapur. ${ }^{50}$

\section{THE COLONIAL ERA}

The seven Crusades fought over the control of the Holy Lands in the twelfth and the thirteenth centuries ended with a decisive defeat of the Christian forces at the hands of the Muslims. With the 'fall' of Constantinople in 1453 the Turks wrested from the Byzantine Empire the control of the Great Silk Route over land that led to India and China. New routes for the spice trade with the East had now to be discovered, if only to escape from the clutches of the 'Moors'. The Egyptian middlemen had been claiming a large cut, as much as 800 per cent, over the original prices of the Indian spices in the European market.

In 1454, Prince Henry of Portugal received from Pope Nicholas V the right to all discoveries as far as India. The Papal Bull "conceded to King Alfonso, the right, total and absolute, to invade, conquer and subject all countries which are under the rule of the enemies of Christ, Saracen or Pagan". The Bull further allowed the King, the Prince "and their successors, [to] occupy and possess in exclusive right the said islands, ports and seas..." It proclaimed that "all faithful Christians are prohibited without the permission of the said Alfonso and his successors to encroach on their sovereignty. Of the conquests already made, or to be made, all the conquests which extend to... all the Orient is perpetually and for the future the sovereignty of King

\footnotetext{
48 Ibid. 306.

49 Ibid. 284.

50 K.M. Panikkar, Asia and Western Dominance: A Survey of the Vasco da Gama Epoch of Asian History, 1498-1945 (London: George Allen and Unwin, 1959, 8th Imp., 1970) 31.
} 
Alfonso." ${ }^{51}$ This was in response to Prince Henry's expressed desire to find a sea route to India "which, it is said, is already subject to Christ," the Bull said: "If he enters into relations with these people, he will induce them to come to the help of the Christians of the West against the enemies of the faith. At the same time, he will bring under submission, with the King's permission; the pagans of the countries not yet afflicted with the plague of Islam and give them knowledge of the name of Christ". ${ }^{52}$

The Papal Bull thus set two objectives for the Portuguese search for India: one, it was necessary to continue the Crusades against the Muslims, from the rear, with the help of people now to be converted into Christianity; two, the geographical discoveries should encourage the spread of the Christian Church.

A number of legal questions could be raised in respect of this Papal Bull. What legal authority did the Pope have to issue such a Bull? Did the Bull, in the fifteenth century, constitute an acceptable basis for "an absolute and incontestable legal title" to Portuguese conquests in the East $?^{53}$ Did Portugal need such an authorisation for assertion of its sovereignty over conquered territories? Since there were sovereign states in existence in the Orient and certainly in India at that time, did the Pope of Rome have authority to confer sovereignty on Portugal in respect of them? Could sovereignty over the seas as well be conferred on Portugal? Could sovereignty be conferred in advance of annexation, according to the international law then pertaining? Some of these questions will be addressed in the subsequent discussion.

The Portuguese reached India when Vasco da Gama landed at the Port of Kozhikode, on the west coast of Kerala, on 27 May 1498, and sought and received permission from the Zamorin (Saamoodiri, the local sovereign) to trade. Thus began the 450 years of European colonialism in India. In November 1510 Alfonso De Albuquerque captured the port of Goa from the Bijapur Sultan; this was followed by the fall of Diu, Daman, Salsotte, Bassein, Chaul and Bombay, San Tom (near Madras), and Hugli (near Calcutta).

On 31 December 1600, the (English) East India Company was formed in London. The Royal Charter granted it "the monopoly of commerce in eastern waters" and nothing more.

On the other hand, the United East India Company of the Netherlands, formed on 20 March 1602 under a Charter granted by the Dutch StatesGeneral, had been specifically empowered to make war, conclude treaties,

\footnotetext{
51 Ibid. 27.

52 Ibid. 26-27. In these pages Panikkar reproduces the whole papal bull. In 1456 Pope Calictus confirmed this bull by a second bull. By the Treaty of Trodesilhas of 9 June 1494, Spain and Portugal fixed a line 370 leagues west of Cape Verde demarcating their colonial zones. Pope Alexander VI was the arbiter.

53 Ibid. 27.
} 
acquire territories and build fortresses: it was "a great instrument of war and conquest". 54

The Danish East India Company took shape in 1616 and its French counterpart in 1664. The Swedish East India Company was formed in 1731, but it exclusively dealt with China.

The British, with a show of force against the Surat traders in the coastal Gujarat, obtained permission from Mughal Emperor Jahangir in 1613 to establish a factory in Surat on the West Coast. By 1619, they had established factories in Surat, Agra, Ahmedabad, and Broach. In 1639 a fortified factory was set up in Fort St. George (Madras). In December 1687, the Directors of the company in London instructed its chief in Madras, most significantly, "to establish such politie of civil and military power, and create and secure such large revenue to secure both ... as may be the foundations of a large, well grounded, secure English domain in India for all time to come."55

In 1690 the English company established a factory at Hugli and in 1698 it was granted by the Mughal emperor zamindari (landlordship) over three villages (one of these became Calcutta).

The aggressive policy of colonial expansionism, endorsed by Oliver Cromwell's Charter of 1657 and also by Charles II and James II, had transformed the English company, originally chartered to be a peaceful trading body, into a political and military power hungry for territorial acquisitions on the Indian subcontinent. The decaying Mughal Empire and the internecine quarrels among local princes facilitated the ready success of this policy. The 1857 uprising was a last-ditch effort on the part of some of the local princes backed by some sections of soldiers and peasants to overthrow the rule of the British company and re-establish the sovereignty of the local princes. This was suppressed with brute force and in 1858, the British Government in London established in India its direct rule, which was finally dismantled only in 1947.

The colonial era has thrown up a number of issues bearing on international law: the legality of the British rule, the status of the 'Indian' states, the use of force and interventionism, the law of the sea, treaty practice, and humanitarian laws of armed conflict.

\subsection{The legal status of the British rule re $^{56}$}

As noted already, the original Charter of the English East India Company authorised the company to establish the monopoly of trade with India. Con-

\footnotetext{
54 Majumdar, op. cit., n. 2 at 633.

55 Ibid. 638-639.

56 See generally, R. Kemal, "The Evolution of British Sovereignty in India', VI Indian Yearbook of International Affairs (1957) at 142-171. See also M.K. Nawaz, "Anglo-Burmese Relations in the Seventeenth Century”, III Indian Yearbook of International Affairs (1954) 141-159.
} 
stitutionally, therefore, at least until the Cromwell Charter of 1657, the company could not legally have acquired and administered territories in India, except for purposes of establishing and maintaining trade with India, unless such acquisitions were ratified or otherwise approved by the British Parliament. It is doubtful, therefore, if the company was legally permitted to resort to force both to establish and to fortify factories, on behalf of the British sovereign. The principle of freedom of trade as generally recognised in the colonial era did not permit such use of force. Indeed, it was a different matter, whether trade, once established, could be protected by use of force under the traditional international law, if the territorial sovereign failed to extend the necessary protection.

In the Island of Palmas arbitration between the US and the Netherlands, Arbitrator Max Huber recognised that the acts of the Dutch East India Company "must, in international law, be entirely assimilated to acts of the Netherlands State itself. From the end of the sixteenth until the nineteenth century, companies formed by individuals and engaged in economic pursuits (Chartered Companies) were invested by the State to whom they were subject with public powers for the acquisition and administration of colonies". Particularly in respect of the Island of Palmas, the arbitrator observed that the native states, of which the island was a part, "were from 1677 onwards connected with the [Dutch] East India Company, and thereby with the Netherlands, by contracts of suzerainty, which conferred upon the suzerain such powers as would justify his considering the vassal State as a part of his territory." 57

Arbitrator Max Huber's doctrine of assimilation of the rights and responsibilities of a company formed by private individuals to those of their national state might have generally held good in respect of the Dutch East India Company, which had been specifically empowered to conclude treaties, make war, acquire territories and erect fortresses. It is doubtful whether it would apply to the English East India Company lock, stock and barrel, except for the general international law of state responsibility, whereby a state is held responsible for the unlawful acts of its nationals under its jurisdiction or control. In other words, the British could not claim rights (including the rights and title to territorial acquisitions) but could only incur responsibility for unlawful acts committed by the English East India Company in India until 1657.

The lack of legal competence and standing on the part of the English East India Company was well realised by the British government itself, when James I had to send a formally accredited ambassador, Sir Thomas Roe, to the Court of Emperor Jahangir at Agra in 1615, and Roe sought to negotiate a commercial treaty with the Mughal Empire between 1615 and 1618. Although he could not persuade the Emperor to conclude a treaty, the Emperor issued a firman (decree of grant) granting certain privileges to the

57 Island of Palmas Arbitration Award, Permanent Court of Arbitration, 1928, 2 UN RIAA 829. 
company. By the time Roe left India in 1619, the company had already established factories at Surat, Agra, Ahmedabad, and Broach, all pursuant to the Mughal firman.

Fort St. George was established at Madras under a lease from the ruler of Chandragiri, representing the Vijayanagar Empire. As for Calcutta, as already seen, the company was granted zamindari (landlordship) by the Nawab of Bengal, as governor of Mughal Empire. K.M. Panikkar recounts that in addressing the Emperor, one of the Presidents of the company described himself as the "smallest particle of sand, John Russel, President of the East India Company with his forehead at command rubbed on the ground". ${ }^{58}$ This symbolised the relationship between the company and the Indian sovereigns, particularly before the infamous Battle of Plassey of 1757, which laid the foundation of the British Empire in India, thanks chiefly to the cunning and treachery of Robert Clive.

There appear to have been three principal views on the legality of British acquisitions in India through the English East India Company. One view was that being a creature of the English law, the British sovereign was responsible for all the actions of the company vis-à-vis other countries according to the Palmas doctrine. As already pointed out, assimilation by the British Government of responsibility for the company's international conduct is undoubted under general international law. However, the same may not be true of whatever rights, if any, 'acquired' by the company through its conduct. Where the company was not constitutionally competent to acquire the rights, such rights might not, as a rule, have accrued to the British government, unless the company had acted as an authorised agent of the government. Could such authorisation even implicitly be given ex post facto, without the consent of the grantor of the rights in question? One very much doubts whether it could.

The second and the third views arose after the 1857 uprising. After quelling the uprising, the British Government, by way of a Queen's Proclamation and an Act of British Parliament ('An Act for Better Government of India'), both of 1858 , took over the government of India. It is generally agreed that the 1858 constitutional changes merely formalised de jure the de facto situation that had existed since 1657. This gave rise to two further views on the status of the British rule in India. There was the argument that beginning with the Battle of Plassey, the company, a vassal of the Mughal Empire, slowly replaced the empire. Yet could a vassal usurp the powers of the emperor to the total defeat of the latter? This position was evidently illegal, and indeed beyond reason.

The third proposition was based on the fact that after the defeat of the Marathas in 1803, the Mughal Emperor was held prisoner, and surrendered all his rights in favour of the company. The Marathas were "the Paramount 'Vakil' (advocates, attorneys) of the Mughals (Vakil-ul-Mutlak, the principal).

58 Panikkar, op. cit., n. 49 at 74. 
The concept of paramountcy might have come from this. Given such a premise, the company could not have legitimately fought these wars at all under British law itself. The Pitts India Act of 1784 had forbidden the company from intervening in the affairs of the Indian States. Yet, the Charter Act of 1813 proclaimed "the undoubted sovereignty of the crown" in and over the possessions of the East India Company! If the original acquisition of these possessions were illegal, and even if it be argued that such illegality could be cured by the British Parliament for purposes of British constitutional law, the question still remains whether the illegality could simultaneously be deemed to be cured on the plane of international law. Nevertheless, those were the days of brute force, and forcible retention legitimised everything; neither logic nor legality had any influence over the matter.

Finally, as if to tie up any legal loose ends, after the death of the last Mughal Emperor, Bahadur Shah Zafar, who was then being held prisoner in Rangoon, Queen Victoria was formally proclaimed "Empress of India" by an Act of 1876 .

\subsection{Status of the 'Indian' state system}

At the arrival of colonial powers in India, there was the awesome Mughal Empire based in Delhi/Agra, which slowly spread southwards and took the weakening Vijayanagara Empire under its wings. There were states totally independent of the Mughal Empire. There were many vassal states of the empire. Some of these themselves had their vassal states. The Mughal attitude to the suzerain-vassal relationship greatly resembled that of the Kautilyan perception of Chakravartin or Vijigishuu. The empire had its own territories directly ruled by it through its governors or viceroys (many of whom were imperial princes) and the vassal states were sovereign for all practical purposes, except that they displayed allegiance to the empire. In other words, their sovereignty was left unchecked, except when they conspired against the empire or failed to pay tributes. They could indeed establish and maintain their own treaty and other foreign relations with other states. They exercised exclusive territorial sovereignty, including criminal, civil and revenue jurisdictions over their subjects.

Thus, when the colonial companies arrived in the East, they were confronted with a full-blown political organisation and state system. In fact, the Indian rulers found it difficult to negotiate treaties with these companies as, in their view, these companies were merely traders and did not represent their national sovereigns. This was one reason why initially they issued the traders with firmans, grants, leases or zamindaris for trading privileges, rather than concluding treaties with them.

The inability of the ordinary European mind to understand and appreciate the Oriental institutions finds expression in Warren Hastings' critique of the overarching legal powers of the dying Mughal Empire. Hastings wrote to 
London: "The King Shah Alam can scarcely be of propriety mentioned among the powers of India. Yet his name and family subsist with the latent rights inherent in them". ${ }^{59} \mathrm{He}$ was obviously unable to understand that allegiance and loyalty, rather than brute force, were the real source of the sustaining power and authority of an Oriental suzerain.

Alexandrowicz highlights the interesting case of the Raja of Banares who was grossly mistreated by the notorious Warren Hastings, the first GovernorGeneral of the English East India Company 1779-1781. Edmund Burke, speaking in support of the Indictment of Hastings at Westminster, explained that Banares was originally a vassal of the Mughal Empire and now a vassal of the company under treaty, that it had its own degree of sovereignty which could not be disregarded by the company, and that the company's treaty with the Raja of Banares could not be breached by Hastings through his raising an expansive and yet false argument that the Raja was only a zamindar. Burke invoked both Indian customary law as well as international customary law to establish that the Raja was entitled to his own place in the traditional hierarchy of sovereigns in India. ${ }^{60}$

"There was no doubt", asserts Alexandrowicz, who has done pioneering research into the history of international law in the Orient, "that the European Powers (companies), on their arrival in India, had to deal with organized political bodies whose legal conceptions facilitated the immediate establishment of mutual relations Far from finding themselves in an area of lawlessness, they were confronted with the existence of a sui generis Family of Nations all over Asia. Its public and private law might have differed from that prevailed in Europe, but it was based on the same principles of justice. The law of nations applied to the relations between East and West in the XVI century and later was law of reciprocity which accepted the sovereignty of Indian and Asian rulers and communities ... It is only after the establishment of the colonial rule in Asia (whether by conquest or treaty) that [the Western] writers of International $\mathrm{Law}^{61}$ started denying Sovereignty to these rulers and communities ... The classic law on the matter has been clear beyond doubt." 62

The expansion of the British colonialism in India took place through numerous interventions, wars and treaties. The British concluded treaties with fully sovereign states, vassal states and states brought under varying degrees of their protection. In other words, beyond the territories directly ruled by the British, there were "Indian States," so designated by the British, with

\footnotetext{
59 Nawaz, op. cit., n. 56 at 151.

60 C.H. Alexandrowicz, An Introduction to the History of the Law of Nations in the East Indies (16th, 17th and 18th Centuries) (Oxford, 1967) 21-23.

${ }^{61}$ E.g., M.F. Lindley, The Acquisition and Government of Backward Territory in International Law (New York, 1926), cited in footnote by C.H. Alexandrowicz, "Grotius and India", III Indian Yearbook of International Affairs (1954) 357-67 at 367.

62 Alexandrowicz. op. cit., n. 60 at 366-67.
} 
varying degrees of external independence. In fact, Queen Victoria's Proclamation of 1858, issued upon the take-over of British India by the British Government, assured "The native princes of India" that

(1) "All treaties and engagements made with them by or under the authorities of the

East India Company are by us accepted, and will be scrupulously maintained".

(2) "We desire no extension of our present territorial possessions and we shall sanction no encroachment on those of others", and

(3) "We shall respect the rights, dignity and honour of native princes as our own."

In practice, however, each of these promises was soon to be broken into shreds. The Act of 1876, whereby the Queen became the Empress of India with effect from 1 January 1877, provided "legal" support for breaches of the above undertaking as well as of treaties and traditional rights of the Indian states. From 1877 onward, the Queen was the Paramount Ruler and the Indian states her "subordinate sovereigns".

The new concept of paramountcy of the British Crown gave rise to serious problems of the integration of the Indian states with the newly independent India or Pakistan in 1947. The British Government took the position that upon Independence, the British paramountcy would elapse and that the rights historically surrendered by the 610 Indian states would revert to them. The Indian National Congress could not "admit the right of any state in India to declare its independence and to live in isolation with the rest of India." "Such a declaration was tantamount to a declaration of war against the free millions of India", declared Mahatma Gandhi; B.R. Ambedkar argued that states could only be sovereign "to the extent they are, but they cannot be independent States so long as they remain under the suzerainty, as they must be, either of the Crown, if India remains a Dominion, or of the successor State, if India becomes independent." ${ }^{" 64}$ Ambedkar's view was probably correct in terms of the contemporaneous traditional international law whereby peacefully achieved succession was automatic.

\subsection{Use of force, interventionism and colonial expansion}

Even as the classical international law accepted the use of force as a legitimate mode of acquisition of territory, it was practised with great abandon and in its most wanton and virulent forms by the European colonialists.

One of the very few peaceful acquisitions made by the British in India was that of Bombay. Bombay was first a Portuguese colony, following Goa, Daman, Diu, Salsette, and Bassein. It was gifted to Charles II of England as part of the dowry of Catherine of Braganza under a treaty of 1661. The

63 Majumdar, op. cit., n. 2 at 844.

64 Ibid. 998-999. 
king transferred it to the English East India Company in 1668 at an annual rent of ten Pounds. The classical international law did not insist on people's consent for such transfers to be valid, as the principle of self-determination had not then taken root.

Leases, the right to fortify trading centres and factories, zamindari and the right to collect revenue were some of the other means of acquisition of colonial territories at least at the beginning of the colonial era. The Indian rulers granted these to the East India Company as they also granted the Company the reduction of or exemption from customs duties.

After 1657, however, the company was prompted both by its masters in London and the British Government to seek an aggressive colonial expansion and it ceased to be a trading company. This change produced ruthless, heartless, barbaric, and downright dishonest British Governors-General/Viceroys such as Warren Hastings, Dalhousie, and Wellesly. Open and wanton use of force even in violation of treaties was the order of the day. The British administration also evolved more 'sophisticated' ways of intervention to intimidate and subjugate the local rulers. Two of these methods were the Subsidiary System and the Doctrine of Lapse. Under the Subsidiary System, the local rulers were forced to enter into treaty relations with the British whereby the British offered protection to them by stationing British forces for their protection, the costs of which would of course have to be borne by the rulers. The Doctrine of Lapse meant that when a local ruler died leaving behind no natural heir, the sovereign power of the ruler lapsed and merged with the British paramountcy. While the Indian customary law permitted adoption as a traditionally acceptable method of appointing an heir, the British Doctrine banned such a practice. ${ }^{65}$

It may be recalled that Section 34 of the Pitt India Act 1784 explicitly prohibited the company from following a policy of non-intervention in the affairs of the Indian States. Also, the Victorian Proclamation of 1858 assured the Indian princes that treaties would be "scrupulously maintained," that the British Government "desire no extension of our present territorial possessions" and that it would "respect the rights, dignity and honour of native princes." Above all, it expressed the desire that the people of India "should enjoy that prosperity and social advancement which can only be secured by internal peace and good governments.",66

\footnotetext{
65 Indeed, after the Queen Victoria's assumption of the title of the "Empress of India" in 1876, this doctrine was revised as reflected in the Instrument of Transfer of Mysore State, 1881. As explained by the British government in 1884, "The succession to a Native States is invalid until it receives in some form the sanction of the British authorities. This was reiterated from time to time." See, Majumdar, op. cit., n. 2 at 845. The Indian customary law required "recognition" of adoption of a child as heir by the sovereign, and the sovereign had never objected to any adoption, as that was the customary practice. The above British policy constituted a rank violation of customary law and practice in India, but abundantly served the colonial interests.

66 Majumdar, op. cit., n. 2 at 844.
} 
Numerous interventions and annexations made by the British in India went without any justification. However, for many others, the British offered at least six excuses for intervention.

\subsubsection{Maladministration}

For example, Governor-General William Bentinck took over the administration of Mysore in 1831 on ground of mal-administration. However, the 'mal-administration' was the direct result of the heavy financial burden imposed on the state by the Subsidiary System. In 1856 the British annexed Oudh on the same ground, despite the existence of an 1837 treaty that should have prevented this.

\subsubsection{Vacant throne}

A large number of states were annexed by the British under the Doctrine of Lapse. Included in the long list were the kingdoms of Nawab of Carnatic (1853), Tanjore (1855), Jhansi (1854), Sambalpur (1850), Udaipur (1852), and Nagpur (1853). ${ }^{67}$

\subsubsection{Cruelty against the subjects}

In 1834, the British falsely charged King Veeraraja of Coorg, a small principality near Mysore, of cruelties against his subjects and of conspiring against the British and annexed his territory without troubling to prove these allegations.

\subsubsection{Enforcement of treaty obligations}

In 1774 Warren Hastings, at the request of the Nawab of Oudh, sent British forces to help the Nawab to enforce a treaty he had with the Ruhelas whereby the latter had promised to pay the Nawab Rupees four million in the event that he helped them in repulsing a Maratha invasion. In the campaign against the Ruhelas, the chief of the Ruhelas was killed, and over 20,000 Ruhelas were expelled from their own territory, later annexed to Oudh, a vassal of the British. Burke, Macaulay, Mill and others castigated Hastings for having "deliberately sold the lives and liberties of a free people and condoned horrible atrocities" against them. ${ }^{68}$

The case of the Begams of Oudh was another standing testimony of shame. In 1782, the British not only intervened to enforce payments far in excess of the amount stipulated in a treaty, against the mother and grand-

\footnotetext{
More on this see ibid. 767-771.

68 Ibid. 692-693.
} 
mother of the Nawab, but also ill-treated and imprisoned them and snatched away perforce their entire private treasury. ${ }^{69}$

\subsubsection{Disaffection and hostility against the British}

The classic case of annexation under this excuse was that of the annexation of the Sind in 1843: The Sind had been used as a base in the British-Afghan wars since 1843. Governor-General Edenborough falsely charged the Amirs of Sind of disaffection and hostility against the British government. As it happened, in reality the Amirs were known for their steadfast loyalty to the British and their scrupulous observance of treaties. The new Resident at Hyderabad (Sind), Charles Napier deliberately acted on the wrong assumption of the Amir's guilt, used force, and annexed the Sind. ${ }^{70}$

\subsubsection{Protection of British traders}

The British merchants settled in Rangoon complained to the British Indian Government, of oppression at the hands of the local Burmese governor. Dalhousie sent a frigate under Commodore Lambert from Calcutta to Pagan, to demand compensation for the losses suffered by the merchants, and to secure the immediate removal of the governor. The Burmese King replaced the governor. Lambert went to meet the new governor at a time when he was asleep and he could not meet him. Angered, Lambert blockaded the Rangoon port, seized a royal vessel, and paved the way for the Second Anglo-Burmese War of 1852, which ended with the annexation of lower Burma by the British.

That the British colonial government also failed to fulfil the Victorian promise of internal peace and good government is generally accepted. In fact, writing in 1945, Jawaharlal Nehru said: "A significant part that stands out is that those parts of India which have been longest under British rule are the poorest today". ${ }^{71}$ The British colonialism destroyed the Indian industry and with it also destroyed the economy and the ancient village institutions. The adverse impact of British colonialism has been all-pervasive.

\subsection{Law of the sea ${ }^{72}$}

As already pointed out, when the Portuguese arrived in India in 1498, there was already an independent state system with well developed rules of

\footnotetext{
69 Ibid. 695-696.

70 Ibid. 761-762. NAPIER admitted in his Diary: "We have no right to seize Sind, yet we shall do so, and a very advantageous, useful, humane piece of rascality it will be". Ibid 763. The company condemned his action, and at the same time appointed him as the first Governor of Sind.

71 Nehru, op. cit., n.13 at 244.

72 See generally, Alexandrowicz, op. cit., n.59 at 41-82; R.P. Anand, Origin and Development of the Law of the Sea: History of International Law Revisited (The Hague, 1983); R.P. Anand, "Mari
} 
inter-state conduct "based on traditions which were more ancient than their own and in no way inferior to notions of European civilisation". ${ }^{73}$

Asians had already been engaged in free navigation and maritime trade in the Indian Ocean and the Arabian Sea. From the first century AD there was commerce between India and Rome. As already seen, the sea-borne trade contributed to the rise of Indian colonial empires in South East Asia.Until the sixteenth century, "there is no doubt about the freedom of navigation and commercial shipping which was exercised by various countries and peoples in the eastern seas, and which led to the development of a number of entrepots and trade centres"',74

The weakening of the Sri Vijaya Empire encouraged Sumatran pirates to disrupt the trade at sea. Kublai Khan's naval expeditions to suppress the pirates in 1292 led to the suppression of piracy and restoration of order. The Ming dynasty also sent similar expeditions in 1405 and 1431.

The hundred years of conflict between the Chola Empire of South India and the Sri Vijaya Empire led to the weakening of both and the Arabs emerged as the leaders of the sea-borne trade in the region. Yet there was never interference with the traditional freedom of navigation and commerce. Although the rules of the sea-borne trade were largely customary in character, there were at least two instances of codification. Towards the end of the fifteenth century, Sultan Mahmud Shah authorised a maritime code in Malacca and a similar maritime Code of Macassar also emerged around the same time. Resisting the Dutch attempts at prohibition of all non-Dutch trade with the Spice Islands, the ruler of Macassar proclaimed in 1615:

"God has made the earth and the sea, has divided the earth among mankind and given the sea in common. It is a thing unheard of that anyone should be forbidden to sail the seas". 75

Thus it is clear that by the time the European colonialists appeared on the Asian scene, the Asians (including the Arabs) had already established and were consistently practising among themselves the principle of the freedom of the seas, the rules of flag state jurisdiction on the seas, superior coastal jurisdiction over all ships while near the coast, prohibition of piracy, rules of charter-party, customs and tolls, permits of entry and departure, and even some rules relating to contraband.

While this generally well-developed maritime practice existed in the Asian region, the situation in Europe was anarchic, states frequently following the

time Practice in South-East Asia until $1600 \mathrm{AD}$ and the Modern Law of the Sea", in his International Law and the Developing Countries (New Delhi, 1986) 53-71.

${ }^{73}$ C.H. Alexandrowicz, "Afro-Asian World and the Law of Nations (Historical Aspects)," 123

Recueil des Cours (Hague Academy of International Law) (1968-69) 117-124 at 124.

${ }^{74}$ Anand, "Maritime Practice in South-East Asia....", op. cit., n. 72 at 57.

75 Quoted, ibid. 59. 
doctrine of mare clausum. ${ }^{76}$ Acting under the Papal Bull of 1454, Vasco da Gama and Pedro Alvarez Cabral asserted Portuguese supremacy over the eastern seas, by depriving the merchants of other nations of their traditional right to maritime trade, and by looting and plundering their ships. ${ }^{77}$ When Alfonso De Albuquerque arrived on the Malayan coast in the early seventeenth century, he had noticed Arab, Hindu and Chinese traders competing openly in the markets of that area. ${ }^{78}$ The Portuguese, however, did not respect the maritime customary law of the East. ${ }^{79}$

As the Dutch came to challenge the Portuguese supremacy in the eastern seas, their rivalry produced Hugo Grotius to advocate the doctrine of the freedom of the seas in favour of the Dutch. ${ }^{80}$ As an assertion of their claim of sovereignty over the Eastern Seas, the Portuguese also introduced a system of cartazes (safe-conduct passes) forcing foreign ships to seek from Portuguese authorities safe conduct, on pain of search, seizure and confiscation at sea. ${ }^{81}$ Subsequently, however, when some of the Indian states (for instance, the Marathas) too started issuing cartazes, these became merely certificates of clearances, perhaps relevant to determination by a coastal state of the innocence of the passage of a foreign vessel. ${ }^{82}$

The effect of colonialism over the Eastern Seas has been the general erosion of the earlier customary maritime practice based on the doctrine of mare liberum.

\subsection{Treaties $^{83}$}

At least seven aspects of treaty practice of this era may be highlighted. They relate to secularisation of treaty law, the concept of unequal treaties,

\section{Ibid. 60.}

77 Majumdar, op. cit., n. 2 at 631-32. Panikkar cites an example of special Portuguese cruelty to the Muslims, from Lendas da India.During his second voyage to India, Vasco da Gama captured an unarmed vessel returning from Mecca. After looting it, he prohibited all 'Moors' (Muslims) from escaping from the vessel and set it afire. See Panikkar, op. cit., n. 50 at 35.

78 Panikkar, op. cit., n. 5 at 30.

79 As Panikkar quotes Barroes, a Portuguese historian:-

"It is true that there does exist a common right of all to navigate the seas and in Europe we recognize the rights which others hold against us; but the right does not extend beyond Europe and therefore the Portuguese as Lords of the Sea are justified in confiscating the goods of all those who navigate the seas without their permission".

Ibid. 35. Barroes' blatant statement comes in justification of plunder and massacre of a ship returning from Mecca, referred to in n. 77 above.

80 For more on this, see Alexandrowicz, op. cit., n. 60 at 61-82.

81 See ibid. 71-71.

82 Alexandrowicz considers the cartazes to be a forerunner of the navicert in practice during war, introduced by the British. See ibid. 73.

83 See generally, Alexandrowicz, op. cit., n. 60 at 83-97, 158-184. 
personal treaties, authority to conclude treaties, treaty law as evidenced by the Right of Passage case, capitulatory treaties, and treaties with discriminatory clauses in respect of trade.

\subsubsection{Secularisation of treaty law}

The advent of the Europeans in the Orient also highlighted the diverse treaty practices. To begin with, there was a novelty for the Christian states of Europe to conclude treaties with non-Christian powers as such. When Francis I of France entered into a treaty with Suleiman the Magnificent of the Ottoman Empire in 1535, he had to send a letter of apology to the Pope. ${ }^{84}$ From the Islamic point of view, too, to establish treaty relations with non-Islamic countries was revolutionary, since the Islamic legal theory divided the world into Dar-al-Islam (where Islam prevailed) and Dar-al-Harb (the rest of the world). Subsequently, a third region (i.e., Dar-al-Ahd), consisting of countries with permanent agreements with Islamic countries, was added. ${ }^{85}$ Slowly, however, the treaty law was secularised. The Ottoman and the Persian empires developed treaty relations with non-Muslim countries. The Mughals stood apart. According to Alexandrowicz, the "Mughal reluctance to conclude treaties had little to do with religious motives derived from Islamic doctrine. It was simply a manifestation of imperial superiority and perhaps a sign of caution similar to that advocated the Kautilyan school of thought". ${ }^{86}$ This was the reason why Thomas Roe failed to conclude a commercial treaty with Jahangir. Yet the English and the French East India companies were granted trade privileges through firmans or conferment of the status of vassals. However, the Europeans could eventually establish a network of treaty relations with various other Indian rulers (including Muslim rulers). ${ }^{87}$

\subsubsection{Equal and unequal treaties}

Most of the early treaties concluded between the European companies and the Indian rulers had been treaties of commerce. Alexandrowicz quotes G.F. De Martens' remark that the commencement and carrying on of com-

\footnotetext{
${ }^{84}$ Francis I wrote the letter of apology to Pope Paul III with this concluding sentence: "Differences of religion and cultural tradition cannot destroy the natural association of mankind". See Alexandrowicz, op. cit., n. 73, 117-214 at 127-128.

${ }^{85}$ Ibid. 90. Abyssinia was an example.

${ }^{86}$ Alexandrowicz, op. cit., .n. 60 at 93. The Kautilyan counsel of caution to preserve the freedom of action of a ruler by not concluding a treaty, could apply to many East Indian rulers of that time. See ibid. 149.

87 In Alexandrowicz's view, "treaty practice with East Indies contributed significantly to the secularisation of the law of nations". Ibid. 94.
} 
merce between the Europeans and the Indian nations were only possible if the latter "are willing to admit it". 88

The treaty practice in India after the arrival of the European colonialists produced both equal and unequal treaties. The initial treaties of commerce and grant of special privileges (including jurisdiction over foreigners) were by and large equal treaties. As the activities of each of the European companies started focusing less and less on trade and more on the establishment of a colonial empire in India by conspiracy and policies of intervention, annexation and subjugation, the treaties they concluded or forced upon the local rulers came to be unequal. These included treaties of subsidiary alliances, ${ }^{89}$ treaties of cession, many boundary treaties, and treaties of peace coupled with one-sided war claims compensation. Treaties subjected to wanton violation by the British in India were a legion. The case of annexation of the Sind has already been discussed. The Marquis of Hastings seems to hold the distinction of converting a large number of treaties "of reciprocity and mutuality" into one of "subordinate co-operation" in order to establish British paramountcy over the India rulers. ${ }^{90}$

\subsubsection{Personal treaties}

The British at times found it convenient not to recognise certain treaties as binding on both Britain and the relevant Indian state on a permanent basis, but to require them to be re-negotiated upon the succession of a new ruler. In other words, depending on the respective situations, they regarded certain treaties to be "personal treaties" ceasing to be effective on the death of a ruler. The new ruler was required to re-negotiate them. ${ }^{91}$

\footnotetext{
${ }^{88}$ G.F. De Martens, Compendium of the Law of Nations (W. Corbett, trans., 1802) at 152, cited in Alexandrowicz, op. cit., n. 60 at 153.

89 The Treaty of Bassein of 31 December 1802 is an example of a subsidiary alliance between the British and the Peshwa of Persia. The Peshwa applied to Wellesley for protection against the Bhonsle and the Sciendia. Under the treaty, the British agreed to station 6000 British troops in the Peshwa's territory "in perpetuity". For their maintenance, territories yielding Rs. 2.6 million per annum were surrendered to the British. The Peshwa also agreed not to entertain any European power inimical to the British, and subjected his relations with others to the control of the British. See Majumdar, op. cit., n. 2 at 700-701.

90 Majumdar, ibid. 764.

91 Thus, when the old Afghan Amir died in September 1901, Lord Curzon insisted that the new ruler renew a previous friendship treaty. The ruler argued that that treaty subsisted in force, being one between the two countries. Curzon asserted that it was a personal treaty whose validity did not survive the deceased ruler. Finally, another treaty had to be negotiated in 1905. See Majumdar, ibid. 904.
} 


\subsubsection{Authority to conclude treaties}

Ordinarily, it was taken for granted that the governors of the British Presidencies had the authority to conclude treaties on behalf of the British Company. However, on occasion, considerations of political expediency led to the countermanding of the governor's authority. Thus, in 1775 when the Bombay governor concluded a treaty (the Treaty of Surat) with the Peshwas, although Warren Hastings was not opposed to it, the Supreme Council of the company at Calcutta condemned the governor's action as being "impolite, dangerous, unauthorized and unjust", and instead authorized with the opponents of the Peshwas on 1 March 1776 the conclusion of another treaty, which also annulled the Treaty of Surat. ${ }^{92}$

\subsubsection{The Right of Passage case and the treaty law}

In those days, while negotiating a treaty between a European power and an Indian ruler, it was usual for the European party to prepare its draft in its own language and send it across to the Indian ruler who would get it translated into his language, examine it, and return it with necessary amendments or revision. Finally the treaty evolved in two languages, each party executing its own language text. Such a practice led to India's contention in the Right of Passage case that there existed no Treaty of Poona of 1779, since there existed no single mutually accepted and binding text of the treaty. India also pointed to the divergence between the Portuguese and the Marathi texts of the treaty. Rejecting the Indian objections, the International Court of Justice held: -

\footnotetext{
"The Court does not consider it necessary to deal with these and other objections raised by India to the form of the Treaty and the procedure by means of which agreement upon its terms was reached. It is sufficient to state that the validity of a treaty concluded as long ago as the last quarter of the eighteenth century, in the conditions then prevailing in the Indian Peninsula, should not be judged upon the basis of practices and procedures which have since developed only gradually. The Marathas themselves regarded the Treaty of 1779 as valid and binding upon them, and gave effect to its provisions". ${ }^{93}$
}

The Court's pronouncement bears out a number of implications for international law. Firstly, for the first time the International Court held that a 1779 agreement between an Indian (i.e., Oriental) ruler and a European power to be a valid treaty under international law. Secondly, this means that the competence of both parties to conclude a treaty was never doubted. The Court thus rejected the European doctrinal perception of international law that it

92 Ibid. 677.

93 Rights of Passage over Indian Territory case (Portugal v. India), ICJ Rep. 1960: 6 at 37. 
was a system of law applicable to the European or Christian nations only, and not to others. Thirdly, the Court recognised the validity of established treaty practice of the countries of the Orient, and held that, according to the doctrine of inter-temporal law, the circumstances of conclusion of a treaty, the validity of treaty practices, the validity of the treaty itself, and even the interpretation of the treaty: all must depend on the intrinsic and extrinsic contemporaneous evidence.

On the question whether Article 17 of the Treaty of 1779 constituted a cession of territory, the Court ruled thus:

"From the examination of the various texts of that article placed before it, the Court is unable to conclude that the language employed therein was intended to transfer sovereignty over the villages to the Portuguese. There are several instances on the record of treaties concluded by the Marathas which show that, where a transfer of sovereignty was intended, appropriate and adequate expressions like cession 'in perpetuity' or 'in perpetual sovereignty' were used." 94

On an analysis of the contemporaneous practice of states in India (at a time when the Mughal Empire was in ferment, when even the person of the Emperor was under the control of the Marathas, the myth of de jure paramountcy of the Emperor still ruled over the subcontinent), the Court further concluded that "what was granted [by the Marathas] to the Portuguese was only a revenue tenure," commonly described as a grant of jagir (the Mughal law) or a saranjam (the Marathi practice). ${ }^{95}$

Finally, the Court appears to have assumed the competence of the Portuguese East India Company to conclude such treaties with Oriental sovereigns. It did not separately consider this issue. Possibly, perhaps, it thought that, in terms of the then prevalent Indian practice (and the practice of the European powers, recognized in the Island of Palmas case), the question did not arise.

Be that as it may, the cumulative effect of the Court's judgment is to demonstrate that the international law of the 18th century was not confined to the Christian nations of the West, but that the universality of international

\footnotetext{
94 Ibid. 38.

95 Id. The Portuguese - Maratha Treaty of 1779 between Dom Jose Pedro da Camara, Governor of Goa and Madhav Rao Pandit Pradhan, Peshwa of Poona, is an amazing document. It deals with the freedom of the high seas for each other's ships, duties of mutual assistance at sea, freedom of trade, assistance in the return of each other's escapee slaves, foreclosure of past disputes, settlement of future disputes through good faith negotiations, safety of each other's vessels, mutual assistance in battle at sea, prevention of treasonable activities in either party's territory against the other, denial of assistance to each other's enemies, mutual non-aggression, return of fugitives, Portuguese duty not to fortify any further territories in Maratha territory, return of Portuguese trading vessels found in Maratha jurisdiction, grant of a jagir to the Portuguese towards Daman and compensation for damage to a Portuguese frigate since returned to the Portuguese. For the text of the treaty, see ICJ Pleadings in the Right of Passage case, Vol. III: 336-367.
} 
law transcended the Christian frontiers, and that contemporaneous practice of inter-state conduct was critical for the determination of the existence, nature and content of an international law rule. Very clearly, that which the Court held in respect of the Marathas would apply mutatis mutandis in relation to all Oriental and African sovereigns of that time.

\subsubsection{Capitulatory treaties}

Treaties whereby a sovereign usually conceded to foreign sovereigns criminal jurisdiction over their nationals within the territory of the former were probably introduced by the colonial powers. As already seen, the FrenchOttoman Treaty of 1535 was the first capitulatory treaty between a European power and a non-European (Asian) power. One of the early capitulatory treaties concluded between an Indian ruler and a European colonialist was the Treaty of 1663 concluded by the Dutch Company and the ruler of Cochin, the southern neighbour of Zamorin. This treaty contained a number of jurisdictional clauses. It clarified that if a Hindu committed a crime, the ruler would have the territorial jurisdiction over it, whereas if it were committed by a Christian, judges appointed by the Dutch Company would have jurisdiction. However, with regard to a dispute between the subjects of both parties, each party would exercise jurisdiction over its subject. ${ }^{96}$

In Alexandrowicz's view, there are important differences between the Ottoman capitulatory treaties with the European powers, on the one hand, and those between the Indian rulers and the European companies on the other. Initially, most Indian capitulatory treaties had a constitutive effect in the sense that they granted to the European companies jurisdictional powers, which did not exist but for the specific treaty (or firman). Subsequently, however, when capitulatory treaties were concluded between the Indian rulers and the European powers under whom the former became dependent (after the spread of the colonial empire), these were merely declaratory of the jurisdictional powers of the European colonial governments, since most Indian rulers had already become vassals of these governments. ${ }^{97}$ Yet there were also a few special treaties that sought to settle the jurisdictional problems between the European merchants residing in the territory of the English company and merchants residing in the territory of a neighbouring Indian Ruler, by providing for "presentation of cases through the diplomatic channel to the highest executive authority on one or the other side and it was the latter's duty to have the case assigned to the proper judicial agency". 98

\footnotetext{
96 C.H. Alexandrowicz, "Treaty and Diplomatic Relations between European and South Asian Powers in the Seventeenth and Eighteenth Centuries," 100 Recueil des cours (1960-II) 203-320 at 253.

97 Alexandrowicz, op. cit., n. 60 at 111-112.

98 Ibid. 113-114. Alexandrowicz cites Article XIV of the Treaty of 1788 concluded between the English East India Company and the Vizier of Oudh.
} 
Initially, the capitulatory treaties must have evolved based on a concern for affording justice to foreigners through a system of law with which they were comfortable. ${ }^{99}$ Subsequently, however, they became an effective tool of imperialism, finally to be replaced altogether by the law and the legal system of the colonial power to govern the entire colony.

\subsubsection{Treaties with discriminatory clauses}

European companies also introduced in India the practice of treaties, which provided for inter-European discrimination, even if inconsistent with the principle of freedom of trade. ${ }^{100}$ This was due chiefly to the export to the Orient of intra-European rivalries. Each European company sought to establish its monopoly over the spice trade in the territory of an Indian ruler to the exclusion of other European companies. These attempts at monopoly later expanded to cover trade in all commodities. Slowly but surely, the granting by an Indian ruler of a commercial monopoly to one European company to the exclusion of others led to the Indian ruler's isolation and a position of inequality, and finally to his subjugation. Commercial monopoly was soon replaced by European control of foreign policy of the Indian ruler, and this was further replaced by subsidiarity and total loss of independence.

The Treaty of 1604 between the Zamorin of Kozhikode and the Dutch East India Company expressed the common policy of the parties to eliminate the Portuguese from the whole of India. The Treaty of 1612 between the Vijayanagara Empire and the Dutch stipulated that the king should prohibit the Portuguese from residing and trading at Pullicat, where only the Dutch should be allowed in. It also provided that "the king shall ... not be permitted to allow any European nation (to) traffic here", except those licensed by the Dutch Prince. ${ }^{101}$ By a Treaty of 1792 , the Nawab of Carnatic agreed with the English company not to negotiate or correspond with any European power "without the consent" of English company.

The 1759 treaty between the English company and Hyderabad (Deccan) was specifically anti-French. Under a further treaty of 1798, the Nizam of Hyderabad surrendered to the English his right to negotiate with other states. The treaty of 1800 truly converted him to a subordinate position in relation to the English.

The Marathas too concluded the treaty of 1782 with the English, undertaking not to allow any other Europeans than the English and the Portuguese into their territories and not to have intercourse with any other European nations. In return, the English company undertook not to assist any Indian nation that was in a state of enmity with the Marathas. The treaties of 1902

\footnotetext{
${ }^{99}$ Alexandrowicz refers to the Dutch-Persian Treaty of 1631 evidencing a prior grant of capitulatory jurisdiction by the Dutch in favour of a Persian merchant community in Amsterdam. See ibid. 19. 100 See generally, Alexandrowicz, ibid. 128-148.

101 Ibid. 132.
} 
and 1803 imposed on the Marathas an obligation to dispense with all nonBritish Europeans in their service. The Treaty of 1817 between the Peshwa and the English reiterated this and also obligated the Peshwa not to send or receive embassies or to communicate with other nations, except through the English Resident (the resident political representative of the company). This was the end of the Maratha sovereignty.

\subsection{War and humanitarian laws of armed conflict}

During the colonial era, the concept of war roughly represented the wanton use of force by the British against the local rulers. For instance, the main justification for the final and savage British assault on the sovereignty of Mysore in 1799 was offered by Governor-General Lord Wellesley in the following words: "The act of Tippoo's ambassadors (seeking alliances), ratified by himself, and accompanied by the landing of a French force in his country is a public, unqualified and unambiguous declaration of war; aggravated by an avowal, that the object of the war is neither expansion, reparation, nor security, but the total destruction of the British Government in India." 102

All wars all through the ages have violated the humanitarian laws applicable in armed conflict. However, colonialism in particular was founded literally on the blood of Asians and Africans. Indian historians cite a number of instances in which the European colonialists provoked war or resorted to unprovoked war with Indian rulers. Portrayed here are some random examples.

Majumdar and associates record that in December 1688, the English blocked Bombay and the Mughal ports on the west coast of India, seized many Mughal ships, and also sent a captain to the Red Sea and the Persian Gulf "to arrest the pilgrim traffic to Mecca". The English were defeated by the might of the Mughal Empire and had to sue for pardon and peace before Aurangzeb. In February 1690, the Emperor granted pardon and restored the English licence to trade, when the English agreed to return all the captured vessels and pay Rs. 150,000 as compensation. ${ }^{103}$

The 1857 uprising had its own share of wanton killings on both sides. The British finally succeeded in quelling the uprising at great human cost. The last Mughal emperor was taken prisoner and deported for life to Rangoon. His sons and grandson were killed on the spot, after being taken prisoner, on a mere allegation of having murdered some Englishmen. ${ }^{104}$ The scene at Delhi, upon entry of the British troops in September 1857, was described by the British-run Bombay Reporter as follows: "All the city people found

\footnotetext{
102 Majumdar, op. cit., n. 2 at 712.

103 Ibid. 639.

104 In the words of Malleson, an English historian, "a more brutal or a more unnecessary outrage was never committed. It was a blunder as well as a crime.” Quoted, ibid. 778.
} 
within the walls our troops entered were bayoneted on the spot; and the number was considerable, as you may suppose when I tell you that in some houses forty or fifty persons were hiding". 105

As Jawaharlal Nehru recounts the horror of the British retaliation to the revolt based on the accounts of some of the British historians, "the days of Timur and Nadir Shah were remembered; but their exploits were eclipsed by the new terror, both in extent and length of time it lasted. Looting was officially allowed for a week, but actually lasted for a month, and it was accompanied by wholesale massacre". In several cities like Allahabad, Kanpur, and Lucknow "bloody assizes" were held by British soldiers and civilians and they, with or without any assizes at all, massacred Indians regardless of age or sex. Even volunteer parties went into districts with amateur executioners. $^{106}$

The standard of compliance with humanitarian laws by the Indian rulers was by and large better than that of the British, although many Indian rulers too recognised no limits on the use of force or on the mistreatment of subjugated people, and plunder and siege of cities. A few rulers were known for their exemplary conduct in this regard. Krishnadeva Raya of Vijayanagara Empire in a war with King Gajapti Prataparudra of Orissa in 1514, captured his fortress of Udayagiri and took the latter's uncle and aunt as prisoners of war, but treated them with due honour. ${ }^{107}$

Chhatrapati Shivaji, the most powerful of the Marathas in the early seventeenth century, was known to have respected women, mosques, and noncombatants, did not permit the slaughter of humans after battle, and released with honour the captured enemy officers and men. "[T]hese are surely no light virtues", says British historian H.G. Rowlinson. ${ }^{108}$

\section{THE MODERN ERA}

Two aspects of modern India's perception of and attitude towards international law are considered here: (a) the Nehruvian perception of international law, and (b) India's contribution to the normative development of modern international law.

\subsection{The Nehruvian perception of international law}

The independent India's attitude and policy on international law began unfolding through the independence movement particularly in the late 1920s

\footnotetext{
Ibid. 777.

106 Nehru, op. cit., .n. 1 at 270.

107 Majumdar, op. cit., n. 2 at 369.

108 Ibid. 522.
} 
and 1930s. That India participated in the San Francisco Conference of 1945 which brought into being the UN Charter, is of little significance, because it was still a British colony; the Indian delegation was appointed by the British Government; en route to San Francisco, it was briefed in London, and it played a subordinate role to London at the conference. India had, therefore, to wait until 1947 to claim its rightful place in the comity of nations.

The independent India's foreign policy and attitude towards international law have been based on its keenness to stay clear of the power politics of rival alliances of states; establish peace, harmony and co-operation, and protect fiercely its own independence such that the destiny of its people be pursued by them in their own way. The colonial experiences have taught India the values of independence and national unity, respect for the independence of other peoples, and international co-operation. In his first radio broadcast, as the Vice-President of the Interim Government of India, Jawaharlal Nehru, the architect of the independent India's foreign policy, said on 7 September 1946:

\footnotetext{
"We propose, as far as possible, to keep away from the power politics of groups, aligned against one another, which have led in the past to world wars and which may again lead to disaster of an even vaster scale. We believe that peace and freedom are indivisible and the denial of freedom anywhere must endanger freedom elsewhere and lead to conflict and war. We are particularly interested in the emancipation of colonial and dependent territories and peoples and in the recognition in theory and practice of equal opportunities for all peoples.... We seek no domination over others and we claim no privileged position over other peoples.... The world, in spite of its rivalries and hatreds and inner conflicts, moves inevitably towards closer cooperation and the building up of a world commonwealth. It is for this one world free India will work, a world in which there is free co-operation of free peoples and no class or group exploits another". ${ }^{109}$
}

Nehru's interest "in the theory and practice of equal opportunities for all peoples" presented a point of confluence of both vision and pragmatism. Indeed, it was part of his world view - a view of peaceful co-existence of states, and of an equitable world order in which countries, both large and small, developed and developing, co-operate with one another. Pursuant to this world vision, Article 51 of the Indian Constitution 1950 enjoins the state to "endeavour to - (a) promote international peace and security; (b) maintain just and honourable relations between nations; (c) foster respect for international law and treaty obligations in the dealings of organized people with

109 Jawaharlal Nehru's broadcast speech on the All India Radio, 7 September 1946, reproduced in extenso in The Hindustan Times (New Delhi) and The Hindu (Madras), of 8 and 9 September 1946, respectively. 
one another, and encourage settlement of international disputes by arbitration." 110

Nehru's views of international order, international organisation and international law received expression in his numerous public statements. Specifically on international law, Nehru on two occasions, in 1959 and 1963, addressed the Indian Society of International Law, in the establishment of which he along with his Defence Minister, V.K. Krishna Menon, had played an important role. He rejected the claim that international law originated in the West and that "there was no such thing in the countries of Asia or elsewhere". There was indeed some kind of international law in ancient India, China and elsewhere, he asserted. ${ }^{111}$ While most of the ancient ideas might be out of line with modern life, he viewed the ethical content of these ideas to be of perennial significance. On a philosophical plane, he reduced most great problems of the day to two "major facts" behind them, namely (a) the immense and continuous advance in science and technology which was changing human life and gave increasing power to humanity, and (b) the possible misuse of this great power. "This has resulted in an atmosphere of fear in many parts of the world leading to stultified thought and frightened action". ${ }^{112}$ The reason for this, according to Nehru, was that the scientific and technological developments had far outstripped the cultural development of man, which latter alone could have placed restraints on the misuse of power. Immense power without ethical restraints underlay the great problems of the modern world. Added to this were the new challenges, posed to the world community by the scientific and technological developments. From this point of view, the political boundaries of states became irrelevant.

Against such a scenario, Nehru envisaged a role for modern international law in dealing with modern problems. These problems include those of "autonomy" between international and national entities (which "is being sought to be resolved in the present day attempts at international organisation"), ${ }^{113}$ impact of scientific and technological advance on the international order, ${ }^{114}$ disarmament (where international law, along with other forces, could influence action), and the elimination of nuclear weapons and nuclear tests.

An important objective of international law, according to Nehru, was to promote "understanding of peace between nations", which include "good relations" among nations, elimination of war, peaceful settlement of disputes

110 For a study of this provision, see P. Chandrasekhara Rao, The Indian Constitution and International Law (New Delhi, 1993) 7.

111 Address by Prime Minister Nehru inaugurating the Indian society of International Law in 1959, op. cit., n. 1 at 6.

112 Ibid. 8.

113 Ibid. 6.

114 "It may be said that international organisation and international law have not kept pace with this advance which is posing so many problems before us", said Nehru, id. 
and international co-operation. ${ }^{115} \mathrm{He}$ was concerned that while international law had considerably expanded, its effectiveness had not done so in equal measure. The latter was a function of commitment to and acceptance of the law by all nations, big and small, predicated upon the capability of the law to help them tackle modern problems. It was a function of disarmament and an acceptable international order and international authority. ${ }^{116}$ "There is not much of a choice left between some international order, international authority, and the ever present danger of a major war between nations", said Nehru. ${ }^{117}$

The United Nations, in Nehru's perception, reflected "a very noble attempt to bring the world into some scheme of international law. The Charter of the United Nations is a very fine and inspiring document - I mean the objectives and ideals that it sets before itself." 118 Noting the criticism that the UN had not lived up to its ideals, he said: "That criticism is both justified and unjustified - justified because it is true and unjustified because the United Nations has only to function in the world as it is. It cannot function in some rarefied atmosphere, which is away from the world ... Nevertheless, here is something which keeps this ideal of some kind of world order, the international law applied to the world before us. It is true that in practice it is not applied, in the opinion of many, as justly and as equitably as it ought to be. Great interests pull the United Nations, this way or that ... Groups of nations pull it in various directions. It may be so, but the ideal is there and that itself is a great gain". ${ }^{119}$

Nehru was aware of the Euro-centric character of the traditional international law, which evolved at a time when most part of Asia and Africa was on the periphery of the European sovereign state system. Hence his support for the establishment of the Indian Society of International Law and the Asian-African Consultative Committee (now, Organisation), the former to evolve an Indian viewpoint on aspects of international law, and the latter to forge a common front amongst the Asian and African nations on the great contemporary issues of relevance to international law.

\subsection{India's contribution to international law making}

In view of the limitations of space, the present paper confines itself to identifying eight areas of international law wherein India's normative contribution has been widely acknowledged, namely, the Declaration on Friendly

\footnotetext{
115 Id.

${ }^{116}$ Proceedings of the Annual Conference of the Indian Society of International Law, 1963, 4-6 at 4-5.

117 Ibid. 5.

118 Op. cit., n. 1 at 7.

119 Ibid. 8.
} 
Relations of 1970, the law of the sea, the law of outer space, equity in international economic relations, human rights and decolonisation, international terrorism, the law of the environment, and the law of disarmament.

\subsubsection{The Declaration on friendly relations, 1970}

The expression "friendly relations and co-operation among States in accordance with the Charter of the United Nations" is the United Nations euphemy for the phrase "peaceful co-existence", and was evolved on the basis of Article 1 of the UN Charter, in view of the Western misgivings about the latter. However, peaceful co-existence has had a specific meaning in the terminology of the Non-alignment, its legal content deriving from the Panchsheel, first embodied in the Sino-Indian Treaty of 1954.

The UN General Assembly decided in 1961 to launch upon negotiating the formulation of the Declaration, in response to a concerted move by the 'Third World' countries, often supported by the Soviet bloc. The end of the Second World War had brought with it momentous changes in international relations. The "old order" gave way to a "new order" dominated by two superpowers, with each presiding over its own bloc of countries, and each promoting political and ideological confrontation and proxy-wars against the other. Hiroshima and Nagasaki proclaimed the arrival of the nuclear weapons, which triggered a nuclear arms race between the two power blocs. While colonialism started disappearing, it needed a push to hasten its end.

The large-scale emancipation of the countries of Asia and Africa from the yoke of colonialism brought about a sea change in "the geography of international law," in the words of Judge Radha Binod Pal. While these countries shared the experiences of colonialism and exploitation, they also wanted to build upon this shared history, a framework of co-operation. To them, the condition of international peace and security was essential for marshalling all available sources for their economic development, for the reconstruction of the internal political, economic and social systems from the rubble of the erstwhile colonial devastation.

Thus, these countries of Asia and Africa wanted to redefine, refine and reorient the normative foundations of international law. The traditional international law has been a product of Euro-centric international relations since the Middle Ages. Much of that law served the interests of Western states, and operated to the detriment of the "new" states. The latter had, furthermore, played no part in the making of the traditional international law. Hence their demand to redefine, refine and re-orient the international normative order to the needs of the contemporary international community and to participate in the new consensus underlying this lawmaking process.

Finally, the decade-long intense negotiations between the West, the East and the Third World culminated in the consensual adoption of the Friendly Relations Declaration in 1970. The Declaration embodies formulations of the seven principles of modern international law, namely, prohibition of the 
use of force, non-intervention, peaceful settlement of international disputes, international co-operation, equal rights and self-determination, sovereign equality, and fulfilment in good faith of international obligations.

The Indian delegation, under the leadership of K. Krishna Rao, the then Legal Adviser in the Ministry of External Affairs, Government of India, played a seminal role in the evolution of the declaration. India's contributions to the formulations of the prohibition of force, of non-intervention, selfdetermination and international co-operation have been particularly noteworthy. The balancing of the right of self-determination of peoples with the territorial integrity of an already independent State is especially important in that the territorial integrity of a state with a representative government in compliance with the principle of self-determination may assume itself to be protected from claims of secession. ${ }^{120}$

\subsubsection{The law of the sea}

The traditional law of the sea, including the Geneva Conventions of 1958, by and large, provided for a free-for-all regime of the high seas. The freedom of the seas doctrine, from the viewpoint of the exploitation of resources of the sea favoured the powerful and technologically more advanced countries, rather than the developing coastal states. ${ }^{121}$

Ever since the Third Conference of Heads of State or Government of the Non-aligned countries in Lusaka 1970, the Non-Aligned Movement consistently highlighted its special interest in the process and success of the law of the sea negotiations that had commenced at the United Nations in $1967 .{ }^{122}$ It was conscious of the special linkage that existed between its demand for a New International Economic Order (NIEO) and the law of the sea, on the one hand, and the potential of the latter to contribute to the economic development of the Third World, as borne out by Article 29 of the Charter of Economic Rights and Duties of States, 1974 , on the other. ${ }^{123}$

${ }^{120}$ For more on the drafting history of the Friendly Relations Declaration, see V.S.Mani, Basic Principles of Modern International Law: A Study of the United Nations Debates on Principles of International Law Concerning Friendly Relations (New Delhi: Lancers, 1993). The ICJ in its Nicaragua ruling recognised the jural character of the formulations of the Friendly Relations Declaration, see ICJ Rep. 1996: 14 at 100.

121 See R.P. Anand, "Tyranny of the Freedom of the Seas Doctrine", International Studies (New Delhi) (1973) 416-429.

122 See the Ministry of External Affairs, Government of India, Two Decades of Non-Alignment: Documents of the Gatherings of the Non-Aligned Countries, 1961-1982, and Final Documents, 7th Conference of Heads of State or government of the Non-Aligned Countries, (New Delhi, March 1993) 28-129, 138-139.

123 The Fourth NAM, Algiers, 1973, reaffirmed "the vital importance of a rational utilisation of the resources of the seas and oceans for the economic development and promotion of welfare of the peoples". See Ministry of External Affairs, op. cit., n. 122 at 8. See also ibid. 98, 117, 135-6, 143. For an Indian perception of the economic aspects of the International Seabed area see Vathsala 
At least six principal factors underlie the Third UN Law of the Sea negotiations 1967-1994, namely, (1) the unrepresentative character of the 1958 law of the sea regime, (2) the emergence of a large number of Third World countries as new participants in international relations, (3) the trends in overexploitation of ocean fishery resources by the technologically developed nations, and the response of the developing coastal states in establishing coastal marine resource regimes as an expression of economic self-determination of these countries, (4) a vast increase in super-power military presence in the world oceans, (5) developments in marine technology pointing to the resource potential of the international seabed area and equally to the possibilities of seabed resource grabbing by the developed countries on the traditional first-come-first take rule (res communis), and (6) the increasing concern for the preservation of marine environment. ${ }^{124}$ The Third World responses to these factors took the shape of coastal resource zones such as the Exclusive Economic Zone, ${ }^{125}$ and the Continental Shelf, as well as the concept of Common Heritage of Mankind (CHM) in respect of the international seabed area. India, along with many other developing coastal states, played an important role in the articulation and development of these new concepts, while keeping in view its own special interests in ensuring freedom of navigation for its ships through international straits and archipelagic waters.

The currents and cross-currents of international political and economic relations since 1980 played havoc with the fate of CHM, highlighted by a high drama of United States withdrawal from the 'gentlemen's agreement on a consensual "package deal" on the basis of which the Convention of 1982 had been evolved, and its subsequent return to the negotiating table, with a compromise formula struck in $1994^{126}$ (which in fact comprised the entire operationality of CHM and hence its linkage with NIEO). This has, it is submitted, left the International Seabed Area bereft of all but the label of Common Heritage of Mankind. ${ }^{127}$

Yet the cumulative achievements of the UNCLOS III are principally fourfold: (a) a functional approach to law of the sea problems, (b) a normative orientation towards equity in the law, (c) the emergence of a legal concept

Mani, "Exploitation of Deep-Sea-Bed Minerals: Some Economic Issues," India Quarterly (1979) 52-66.

${ }^{124}$ For an elaboration of these factors, see V.S. Mani, "The United Nations, Law of the Sea and the Developing Countries," in M.S. Rajan, V.S. Mani, and C.S.R. Murthy (eds.), The Non-Aligned and the United Nations (New Delhi, 1987) 56-79.

125 See Rahmatullah Khan, "On the Fairer and Equitable Sharing of the Fishery Resources of the Oceans", 13 IJIL (1973) 87 and his "The Fisheries Regime of the Executive Economic Zone", 16 IJIL (1976) 169-186; and "Some Reflections on the Legal Implications of Exclusive Fishery Zones", 21 IJIL (1981) 34-545.

${ }^{126}$ See R.P. Anand, "UN Convention on the Law of the Sea and the United States", 24 IJIL (1984) 153-99.

127 R.P. Anand, "Common Heritage of Mankind - Mutilation of an Ideal”, 37 IJIL (1997) $118 \mathrm{ff.}$ 
of Common Heritage of Mankind to apply to international areas, and (d) a focused international concern for the protection of the marine environment.

\subsubsection{The law of outer space}

The emergence of the law of outer space since 1957 has been triggered and influenced mainly by two factors: one, the need to insulate outer space from the super power arms race, and two, the need to make the benefits of peaceful uses of outer space accessible to all states. These, indeed, have been the factors that underscore India's participation in the evolution of the various treaties and the UN General Assembly resolutions in respect of outer space. As a country, which has developed largely indigenous space technology and used it for the national development activities, India's contribution to the work of the UN Committee on the Peaceful Uses of Outer Space has been substantial. Although the United Nations has not been able to prevent military uses of outer space, its contribution towards forging international co-operation in respect of peaceful uses of the space has not been insignificant. ${ }^{128}$

In regard to outer space, India's perception has been clear since the 1960's. In the words of Vikram Sarabhai, the Father of India's space programme:

\footnotetext{
"We do not have the fantasy of competing with the economically advanced nations in the exploration of the Moon or the planets or manned space flights. But we are convinced that if we are to play a meaningful role nationally, and in the community of nations, we must be second to none in the application of the advanced technologies to the real problems of man and society, which we find in our country". ${ }^{129}$
}

India's pursuit of the peaceful uses of outer space has convincingly demonstrated that it is in the process of "unleashing of the vast and unlimited potential benefits of space technology ... virtually touching every facet of human endeavour". ${ }^{130}$

India's contribution to the evolution of the space science, technology and law at the United Nations has been and continues to be substantial.

\subsubsection{Equity in international economic relations}

As a developing country, India has stressed the need for an equitable international economic order. In the context of the international setting of norms, India played an important part in the evolution of the concept of

\footnotetext{
128 See V.S. Mani, S. Bhatt and V. Balakista Reddy (eds.), Recent Trends in International Space Law and Policy (New Delhi: Lancers, 1996)

${ }^{129}$ Quoted in K. Kasturirangan, "Realizing the Dreams of Dr. Vikram Sarabhai", Countdown (JulyOctober 1994) 171-176, cited in V. Balakista Reddy, "Space Law and Policy in India", in Mani, op. cit., n. 128, 15-139, at 115.

${ }^{130}$ U R. Rao, "Space for Sustainable Development", in op. cit., n. 128 at 27-54.
} 
permanent sovereignty over natural resources, the first normative response of the Third World to the economic imperialism of the big powers. The establishment of the United Nations Conference on Trade and Development in 1963, the call for a New International Economic Order and adoption of the Charter of Economic Rights and Duties in 1974, the emergence of the concept of the common heritage of mankind in respect of international areas of outer space and the oceans since 1963, and the endeavours for the protection of the global commons from further degradation: all these have been on the initiation of or facilitated by the active participation of the Third World countries, including India.

Since 1994, however, there seems to be a feeling generally shared by many developing countries, including India, that the new World Trade Organisation has so far failed to usher in an equitable international trade regime.

\subsubsection{Human rights and self-determination}

India's attitude towards human rights may be examined at two levels, namely, at the normative level, and at the level of international politics. At the normative level, India's freedom struggle underscored the importance of normative assertion of human rights. As noted already, Jawaharlal Nehru has stressed the need for establishment of freedom and democracy in all countries. Yet, India gives more importance to group rights such as self-determination (both political and economic), and a proper balance of emphasis between economic, social and cultural rights, on the one hand, and civil and political rights on the other. Its national statutory institutions such as the Judiciary and the National Human Rights Commission have contributed substantially in the internal implementation of human rights. India also played an important role in the negotiations leading to the adoption of the international covenants on human rights 1966, ${ }^{131}$ and the Convention on Elimination on All Forms of Discrimination, 1965.

India has played an active role in the UN decolonisation process, at both normative and operational levels. V.K. Krishna Menon's initiatives in expanding the scope of Article 73 (e) of the UN Charter, broadening the reporting obligation of the Administering Powers to encompass furnishing of all information in full on the colonial territories, and in the General Assembly's adoption of the 1960 Declaration on Decolonisation are still proudly recalled at least in the Indian academic circles.

India's action in liberating Goa in 1961 has been vehemently criticised in Western circles. Despite the unfortunate "Charter-or-no-Charter" speech of C.S. Jha, the then Indian Ambassador to the United Nations, it was an action taken as a last resort to liberate from Portuguese colonialism what was

131 See, K.P. Saksena, "International Covenants on Human Rights," 15-16 Indian Year Book of International Affairs (1966-1967) 96-613. 
historically, culturally and demographically Indian territory; it represented a right and duty of India to assist the struggle for self-determination of the Indians who inhabited these colonies. K. Krishna Rao declared later, during the Friendly Relations debates of the sixties, that colonialism was "permanent aggression" against which the victim peoples had a right of self-defence. ${ }^{132}$

While the Indo-Pakistan war of 1971 involved the general background of relations between the two countries and issues of the legality of the use of force, the question of self-determination also loomed large. It was a case of colonialism in a non-traditional setting. India's action, much criticised in both the Security Council and the General Assembly, was defensible under both the principles of non-use of force and self-determination. ${ }^{133}$

One of the core problems of implementation of human rights at the international level has been the politics of human rights. States take political advantage of international human rights machinery. Precisely for this reason, India opposes international intervention on human rights issues, unless there is a case of gross and persistent violation of human rights such as in South Africa under the apartheid regime. The politics of human rights makes it impossible for any international machinery to function in conformity with the principles of consistency, impartiality and uniform application of substantive and procedural standards, including principles of natural justice. Eclecticism remains the hallmark of international politics, hence of international organisation.

\subsubsection{Legal controls of international terrorism}

The independent India initially saw international terrorism either as part of the Cold War scenario (in which case it was condemnable), or as part of the national liberation movements (in which case any value judgement would depend on which side of the 'war' one supported). However, India's attitude underwent a sea change by the mid-nineteen-seventies when it started to bear the brunt of cross-border terrorism in the Punjab and Jammu and Kashmir, and in its north-eastern states. Since then it has become a party to many antiterrorism conventions. It actively sponsored the SAARC Convention on International Terrorism, 1987, and negotiated terrorism-specific extradition treaties and bilateral treaties of mutual assistance with Britain, Canada, Germany, the former Soviet Union, the UAE, and the US. India is currently pursuing at the United Nations General Assembly negotiation of a compre-

\footnotetext{
132 Krishna Rao also said: "Recourse to arms if the colonial powers insisted on opposing natural aspirations of the people was legitimate....", UN Doc. A/AC. 125/SR. 64, at 5, quoted in Mani, op. cit., n. 120 at 44.

${ }^{133}$ For more on this, see V.S. Mani, "The 1971 War on the Indian Subcontinent and International Law, 12 IJIL (1972) 83-99. See also M. K. Nawaz, "Bangladesh and International Law”, 11 IJIL (1971) 251.
} 
hensive convention to combat international terrorism, ${ }^{134}$ which has received top priority in multilateral negotiations at the UN, thanks to the developments since the 11 September 2001 terrorist attacks on the US.

\subsubsection{The emerging law of the environment}

While the world woke up to the urgent need to prevent further deterioration of the global environment and restore its quality in 1972, India's Prime Minister, Indira Gandhi, gave a forceful presentation of the case for the developing countries at Stockholm; she argued that the measures of pollution abatement could not be at the cost of development so critically important for these countries, as "poverty is the greatest polluter".

By the Rio Summit in 1992, the international community had started appreciating the link between environment and development, as represented by the new slogan of "sustainable development". The establishment of the Global Environmental Facility resulted from the demand of India and other developing countries for a global fund to assist them in meeting environmental obligations. $^{135}$

The role being played by the Indian judiciary in the implementation of international environmental obligations in the domestic arena deserves special mention. ${ }^{136}$

\subsubsection{Disarmament}

India has consistently supported genuine efforts towards the evolution of global obligations towards general and complete disarmament. Its approach to nuclear disarmament has undergone some changes, although it pledges its unqualified support for the cause of the complete elimination of nuclear weapons on the international plane. Since the famous Nehru initiative of 1954, India has strenuously endeavoured to achieve a total ban on all nuclear tests. In 1974 it decided to test a 'peaceful nuclear explosion.' Subsequently, it proclaimed in the 1980s that it kept its nuclear option open. Since the nuclear weapon tests of 11 and 13 May 1998, however, India now considers itself to be a nuclear weapon state, even as it has reaffirmed its commitment to the total elimination of nuclear weapons at the global level. The reason given in support of the 1998 tests are the change in the security scenario on the

\footnotetext{
134 See UN Doc. A/C.6/55/1 of 28 August 2000.

135 See Rahmatullah Khan, "Legal and Institutional Issues Arising out of the Proposed Framework Convention on Climate change," Indo-British Symposium on Global Change, 15-17 January 1992, New Delhi.

136 See Bharat Desai, "Enforcement of Rights to Environment Protection through Public Interest Litigation in India", 33 IJIL (1993) 27-20; Rajakumar Deepak Singh, "Response of Indian Judiciary to Environment Protection: Some Reflections, 39 IJIL (1999) 55-63; P. Leelakrishnan, Environmental Law in India (New Delhi, 1999).
} 
subcontinent, the discriminatory character of the existing international nuclear non-proliferation and transfer of high technology regime, and the need for India to demonstrate its determination to break the global nuclear apartheid. This change in India's nuclear policy has its protagonists as well as critics. $^{137}$

\section{CONCLUDING REMARKS}

This essay reflects an attempt to survey the history of international law through the looking glass of the history of the evolution of the Indian polity from the cradle of an ancient civilisation through the interfaces of its contacts and interactions with other civilisations at divers cross-roads in the passage of time. Quite possibly, the study reveals a typical Oriental civilisation responding to the need to evolve an equitable and peaceful international regime of relations between organised peoples, built on the time-honoured principles of equity, peaceful co-existence, tolerance and human welfare. The journey has not been easy; the road has not been well laid: it was full of treacherous potholes and conceited culverts. Yet, the Indian civilisation seems by now to have consolidated its position in the international arena, and has come to terms with its post-independence role to be a master of its own destiny. Many of the principles of modern international law can indeed be related to a range of the ancient principles of high morality with which the Indian polity has been familiar since time immemorial. Surely, one lesson that comes out of this study is that the tradition of international law was certainly not something that was brought to this ancient land by the European colonialists. In fact, it was ingrained in the political and religious thought that evolved on this land over time. Its doctrinal content was probably more humane and more equitable than its contemporaneous European counterpart.

Quite possibly similar studies in the history of international law must be undertaken in respect of every ancient civilisation. Such a retrospective assessment is likely to have at least one beneficent impact - it will, it is hoped, facilitate the implementation of international law, by providing the necessary ambience to inform the state polity of the cultural imperatives of a co-operative and equitable international regime of relations between organised peoples, readily available in each national society.

While this essay has taken efforts to capture, albeit in a nutshell, some of the positive normative contributions of the Indian polity and the civilisation on which they are founded, it does not claim to portray any neat balance-sheet of India's state practice as such., each important instance of state practice will need to be subjected to a critical contextual examination for that purpose,

137 See, e.g., V.S. Mani, "Symposium on India's Nuclear Tests 1998: Policy and Legal Implications", 38 IJIL (1978) 218-226. 
and that exercise is decidedly too ambitious to be undertaken within the scope of the present endeavour. 